\title{
Prolonged insulin treatment sensitizes apoptosis pathways in pancreatic $\beta$ cells
}

\author{
E Bucris',2, A Beck1, S Boura-Halfon', R Isaac', Y Vinik1, T Rosenzweig 3 , \\ S R Sampson ${ }^{1,2}$ and Y Zick ${ }^{1}$ \\ 1Department of Molecular Cell Biology, Weizmann Institute of Science, Rehovot, Israel \\ 2Mina and Everard Goodman Faculty of Life Sciences, Bar-Ilan University, Ramat-Gan, Israel \\ 3Department of Molecular Biology and Nutritional Studies, Ariel University, Ariel, Israel
}

Correspondence should be addressed to S R Sampson Email sansampson@gmail.com

\begin{abstract}
Insulin resistance results from impaired insulin signaling in target tissues that leads to increased levels of insulin required to control plasma glucose levels. The cycle of hyperglycemia and hyperinsulinemia eventually leads to pancreatic $\beta$ cell deterioration and death by a mechanism that is yet unclear. Insulin induces ROS formation in several cell types. Furthermore, death of pancreatic $\beta$ cells induced by oxidative stress could be potentiated by insulin. Here, we investigated the mechanism underlying this phenomenon. Experiments were done on pancreatic $\beta$ cell lines (Min-6, RINm, INS-1), isolated mouse and human islets, and on cell lines derived from nonpancreatic sources. Insulin $(100 \mathrm{nM})$ for $24 \mathrm{~h}$ selectively increased the production of ROS in pancreatic $\beta$ cells and isolated pancreatic islets, but only slightly affected the expression of antioxidant enzymes. This was accompanied by a time- and dose-dependent decrease in cellular reducing power of pancreatic $\beta$ cells induced by insulin and altered expression of several ER stress response elements including a significant increase in Trb3 and a slight increase in iNos. The effect on iNos did not increase NO levels. Insulin also potentiated the decrease in cellular reducing power induced by $\mathrm{H}_{2} \mathrm{O}_{2}$ but not cytokines. Insulin decreased the expression of MCL-1, an antiapoptotic protein of the BCL family, and induced a modest yet significant increase in caspase 3/7 activity. In accord with these findings, inhibition of caspase activity eliminated the ability of insulin to increase cell death. We conclude that prolonged elevated levels of insulin may prime apoptosis and cell death-inducing mechanisms as a result of oxidative stress in pancreatic $\beta$ cells.
\end{abstract}

\section{Introduction}

Loss of pancreatic $\beta$-cells is a major contributing factor to decreased pancreatic function in both type 1 (T1D) (Herold et al. 2013) and at a later stage in type 2 (T2D) diabetes (Allagnat et al. 2012). Infiltrating $\mathrm{T}$ and B cells and macrophages in T1D release reactive oxygen and nitrogen radicals and destroy $\beta$ cells (Hou et al. 2008).
The low level of antioxidant enzymes in pancreatic $\beta$ cells (Kajimoto \& Kaneto 2004) renders them relatively more sensitive to oxidative stress than other cell types. Several studies indicate that treatment of cultured cells with insulin, or hyperinsulinemia induced in animal models, promotes the generation of reactive oxygen species (ROS) 
(Mukherjee et al. 1978, May \& de Haen 1979, Goldstein et al. 2005a, Barazzoni et al. 2012) or superoxides (Barazzoni et al. 2012). ROS, in turn, can increase oxidative stress and apoptosis in various cell types (Furukawa et al. 2004), including pancreatic $\beta$ cells (Robertson 2004, Eizirik et al. 2008).

The dynamic changes in the pancreas during progression of $\beta$ cell death raise certain questions regarding potential autocrine regulatory effects of insulin on $\beta$ cells (Navarro-Tableros et al. 2004). In general, insulin acts as a growth factor that plays an antiapoptotic role and protects cells from death through activation of the PI3-kinase and ERK signaling pathways (Muller et al. 2006, Jensen \& De Meyts 2009), and insulin therapy can protect $\beta$ cells from deterioration (Del Parigi 2008). It has been shown, however, that hypersecretion of insulin (insulin resistance) may precede $\beta$ cell dysfunction and may be an important factor in the progression to $\beta$ cell failure (Fernandez et al. 2001, Aston-Mourney et al. 2008, Lu et al. 2010). Furthermore, in conditions of energy stress, hyperactivation of the mTORC1 complex, mediated by growth factors including insulin, may induce apoptosis (Gwinn et al. 2008). It was also shown that chronic insulin treatment of RINm pancreatic $\beta$ cell line increases LDH release and potentiates the deleterious effects of $\mathrm{H}_{2} \mathrm{O}_{2}$ on cell survival (Sampson et al. 2010). Consistent with these findings, insulin has a proapoptotic effect on $\beta$ cells exposed to glucose deprivation (Guillen et al. 2008), conditions that reduce the cellular redox potential.

Here, we have investigated in more detail the possible proapoptotic and death-promoting effects of insulin on pancreatic $\beta$ cells, utilizing pancreatic $\beta$ cell lines as well as isolated mouse and human pancreatic islets. The results indicate that long-term treatment (24-48h) with high levels of insulin, under conditions of oxidative stress may jeopardize survival of $\beta$ cells through apoptotic and nonapoptotic death-inducing mechanisms.

\section{Materials and methods}

\section{Materials}

Penicillin and streptomycin (Pen/Strep), Hanks' solution, DMEM, CMRL 1066 medium and trypsinEDTA were obtained from Biological Industries (Bait Haemek, Israel). FBS was from Hyclone Laboratories (Logan, UT, USA). Protein-G Agarose beads and antiactin antibodies were from Santa Cruz Biotechnology. Insulin, collagenase (type XI), protease inhibitor cocktail and 5,6-chloromethyl-2', 7'-dichlorodihydrofluorescein diacetate, acetyl ester (CM- $\left.\mathrm{H}_{2} \mathrm{DCFDA}\right)$ were from Sigma Chemicals. Enzolyte-caspase RH110 Caspase3/7 Assay kit was from AnaSpec Ltd (San Jose, CA, USA). zVADfmk was from MegaPharm Ltd (Raanana, Israel). Mouse insulin ELISA kit was from Mercodia (Uppsala, Sweden). CellTiter-Blue assay kit was from Promega (purchased through Biological Industries, Beit HaEmek, Israel). Monoclonal p-Tyr (PY-20) antibodies were from BD Biosciences (San Jose, CA, USA). Anti MCL-1 antibodies (Ab 32087) were purchased from Abcom (London, UK). Cytokines IL-1 $\beta$ and IFN- $\gamma$ were purchased from MD Biosciences (Ness Ziona, Israel). TNF- $\alpha$ was provided by Prospec-Tany Technogene (Rehovot, Israel). Cytokine mixture (1x-cytomix) consisted of $3 \mathrm{nM}$ TNF- $\alpha, 3 \mathrm{nM}$ IFN- $\gamma$ and $1.5 \mathrm{nM}$ IL- $1 \beta$ (biological activity: $10 \mathrm{U} / \mathrm{ng}$ (TNF- $\alpha$, IFN- $\gamma$ ) and 200 U/ng (IL-1 $\beta)$ ). Human insulin ELISA kits was purchased from Mercodia (Uppsala, Sweden).

\section{Cell cultures}

Mouse insulinoma (MIN6) cells were a gift from Dr J I Miazaki (Osaka University, Japan), and INS-1 cells were a gift from Prof. M Walker (Weizmann Institute of Science, Israel). All other cell lines were obtained from ATCC. INS-1 and RINm cells (passages 15-30) were maintained in RPMI-1640 medium containing 10\% fetal calf serum (FCS), $4.5 \mathrm{~g} / \mathrm{L}$ glucose, $10 \mathrm{mM}$ Hepes, $1.5 \mathrm{~g} / \mathrm{L}$ sodium bicarbonate, $1 \mathrm{mM}$ sodium pyruvate and $1 \%$ Pen-Strep. MIN6 cells (passages 12-32) were grown in DMEM containing $15 \%$ FCS, $11.1 \mathrm{mM}$ glucose, $2 \mathrm{mM}$ L-glutamine, $1 \%$ Pen-Strep and $60 \mu \mathrm{M} \beta$ mercaptoethanol. Chinese hamster ovary (CHO) cells that overexpress the insulin receptor (CHO-T cells, passages 25-32) were grown in F-12 medium with $10 \%$ bovine calf serum (BCS). NIH fibroblasts expressing human insulin receptor (NIH-T cells, passages 20-32) were grown in DMEM with 10\% BCS, human embryonic kidney cells (HEK 293, passages 10-25) were grown in Eagle's Minimum Essential Medium with 10\% FCS and HepG2 cells (passages 20-30) were grown in MEM Eagle-Earle's salt base. Cultures were incubated in $5 \% \mathrm{CO}_{2}$ humidified atmosphere at $37^{\circ} \mathrm{C}$. The medium was changed every $2-3$ days. At $80 \%$ confluence, cells were transferred to 12 -well plates and seeded at $5 \times 10^{5} \mathrm{cells} / \mathrm{mL}$ in serumand glucose-free medium. After $24 \mathrm{~h}$, cells were treated with $\mathrm{H}_{2} \mathrm{O}_{2}(70 \mu \mathrm{M})$ and insulin $(100 \mathrm{nM})$, alone or in combination, for $24-48 \mathrm{~h}$. 


\section{Isolation of murine islets}

Digested pancreases were filtered through 1000 and $500 \mu \mathrm{m}$ sieves, and islets $>75$ and $<250 \mu \mathrm{m}$ were handpicked under a stereoscope. Islets were cultured in RPMI-1640 medium containing $5 \mathrm{mmol} / \mathrm{L}$ glucose, $10 \%$ (vol./vol.) FCS, $2 \mathrm{mmol} / \mathrm{L}$ L-glutamine, 100 units $/ \mathrm{mL}$ penicillin, $100 \mu \mathrm{g} / \mathrm{mL}$ streptomycin and $40 \mu \mathrm{g} / \mathrm{mL}$ gentamycin, and were used within $48 \mathrm{~h}$ of isolation. Experiments were approved by the Animal Care and Use Committee of the Weizmann Institute of Science.

\section{Culture of human islets}

Isolated human islets ( $>90 \%$ purity) were provided by the European Consortium for Islets Transplantation (ECIT; Islet for Basic Research Programme; http://ecit. dri-sanraffaele.org/en/islet-transplatntation/index. html) through a Juvenile Diabetes Research Foundation award $31-2008-413$. Islets were cultured at $37^{\circ} \mathrm{C}$ in a $5 \%$ $\mathrm{CO}_{2}$ humidified atmosphere in CMRL 1066 medium containing $10 \%$ (vol./vol.) FBS, $2 \mathrm{mM}$ L-glutamine, 100 units $/ \mathrm{mL}$ penicillin, $100 \mu \mathrm{g} / \mathrm{mL}$ streptomycin, $0.25 \mu \mathrm{g} / \mathrm{mL}$ amphotericin and $40 \mu \mathrm{g} / \mathrm{mL}$ gentamycin. The medium was changed every other day. Human islets were dispersed by $4 \mathrm{~min}$ incubation at $37^{\circ} \mathrm{C}$ with trypsin/ EDTA. Trypsinized islets were washed with cold CMRL 1066 medium containing 10\% (vol./vol.) FBS, gently pipetted and resuspended in CMRL 1066 containing 10\% (vol./vol.) FBS. Human islets studies received approval from the Weizmann Institute Bioethics and Embryonic Stem Cell Research Oversight Committee.

\section{Insulin secretion}

MIN6 cells or primary human islets were incubated for $60 \mathrm{~min}$ with 0.3 or $3.3 \mathrm{mmol} / \mathrm{L}$ glucose, respectively, in $\mathrm{KRBH}$ buffer $(124 \mathrm{mmol} / \mathrm{L} \mathrm{NaCl}, 5.6 \mathrm{mmol} / \mathrm{L} \mathrm{KCl}$, $2.5 \mathrm{mmol} / \mathrm{L} \mathrm{CaCl}_{2}$ and $20 \mathrm{mmol} / \mathrm{L}$ Hepes, $\mathrm{pH}$ 7.4). Cells were then incubated with 20.0 or $16.7 \mathrm{mmol} / \mathrm{L}$ glucose, respectively, for $60 \mathrm{~min}$ at $37^{\circ} \mathrm{C}$. Cellular insulin content and the content of insulin secreted to the medium was determined using mouse or human insulin ELISA kit (Mercodia, Uppsala, Sweden) according to the manufacturer's instructions.

\section{LDH release}

$10^{5}-10^{6}$ cells $/ \mathrm{mL}$ were seeded in 24 -well plates. Cells were washed, treated with insulin and $\mathrm{H}_{2} \mathrm{O}_{2}$, and the extent of cell death was measured by the LDH assay kit (Roche) according to manufacturer's instructions.

\section{Preparation of cell lysates and Western blotting}

Cultured $\beta$-cells were mechanically detached and centrifuged at $1500 \mathrm{~g}$ for $5 \mathrm{~min}$ at $4^{\circ} \mathrm{C}$. Cells were resuspended in RIPA buffer containing cocktails of proteases and phosphatase inhibitors for $40 \mathrm{~min}$ on ice, centrifuged and the supernatants were collected. Samples of $50-150 \mu \mathrm{g}$ protein were resolved by SDSPAGE under reducing conditions and were transferred into nitrocellulose membrane for Western blot with the indicated antibodies. The intensity of the bands under study was quantified using the NIH Image densitometry program.

\section{Assay of caspase-3/7 activity and cellular reducing power}

Cells $(15,000$ cells/well $)$ or primary human islets (10-15islets/well) were seeded in 384-well plates in $50 \mu \mathrm{L}$ DMEM and treated as indicated. Caspase 3/7 activity was assayed using Enzolyte-RH110 caspase3/7 assay kit (AnaSpec, San Jose, CA, USA) according to the manufacturer's instruction. Fluorescence intensity was measured using a fluorescence microplate reader (Lumitron Electronic Instruments, Lod, Israel) at $\mathrm{Ex} / \mathrm{Em}=496 \mathrm{~nm} / 520 \mathrm{~nm}$. Assays were performed in triplicates. Cellular reducing power was assayed using the CellTiter-Blue cell (CTB) viability fluorimetric assay (Promega). Fluorescence intensity was measured using a fluorescence microplate reader (Wallac Victor 1420 multilabel counter at $\mathrm{Ex} / \mathrm{Em}=560 \mathrm{~nm} / 590 \mathrm{~nm}$ ).

\section{Detection of intracellular ROS accumulation}

Cells were treated with $10 \mu \mathrm{M}$ CM- ${ }_{2}$ DCFDA for $30 \mathrm{~min}$ at $37^{\circ} \mathrm{C}$ in the dark as described (Dembele et al. 2009). Following treatment, cells were incubated with RPMI medium at $37^{\circ} \mathrm{C}$ for $15 \mathrm{~min}$ to recover, and fluorescence of the oxidized product DCEH-DA was monitored using Tecan Infinite F200 fluorescence microplate reader (Ex $485 \mathrm{~nm}, \mathrm{Em} 520 \mathrm{~nm}$ ). Values for each well were corrected for intracellular protein and background fluorescence. Alternatively, cells $\left(4 \times 10^{5} / \mathrm{mL}\right)$ were grown on cover slips in multiwell plates, treated with the CM-H2DCFDA reagent $(20 \mu \mathrm{M})$, fixed, and the fluorescence intensity of DCEH-DA was monitored by fluorescence microscope (Ex 460-500 nM, Em 510-560 nm).

Published by Bioscientifica Ltd. 


\section{Quantitative real-time PCR (qRT-PCR)}

RNA was extracted using the PerfectPure RNA kit (5Prime, Gaithersburg, MD, USA), and cDNA was generated by cDNA Reverse Transcription kit (Applied Biosystems). Quantitative detection of specific mRNA transcripts was carried out by real-time PCR using ABI-PRISM 7300 instrument (Applied Biosystems) using SYBR green PCR mix (Invitrogen) and the following primers: miNos: forward 5'-GCCCTGCTTTGTGCGAAGTG-3', reverse-5'-AGCCCTTTGTGCTGGGAGTC-3'; mTrb3: forward 5'-GTAGAGGGACCTTTGCCCTG-3'; reverse 5'-GCCGTGATCCTCTCTCAACC-3'; mChop: forward 5'-CCTTCGACCAGTCGGGTTTG-3', reverse 5'-GTCGCTGGAGAACCCATGAG-3'; mAtf4: forward 5'-CCTTCGACCAGTCGGGTTTG-3', reverse 5'-GTCGCTGGAGAACCCATGAG-3'; mBip: forward5'-GGCACCTTCGATGTGTCTCT-3', reverse 5'-ATGACCCGCTGATCAAAGTC-3'; $m X b p 1$ : (spliced isoforms): forward 5'-AACTCACGGCCTTGTGGTTG-3', reverse 5'AGGATCCAGCGTGTCCATTC-3'. Superoxide dismutase 1 (Sod1) (204bp) forward 5'-tgcagggcgtcattcactt-3', reverse 5'-caacatgcctctcttcatcc-3'. Sod2 (197bp) forward 5'-cacattaacgcgcagat-3', reverse 5'-ctcaggtttgtccagaaa-3'. Catalase (Cat) (220 bp) forward 5'-agcagtggaaggagcagc-3', reverse 5'-tcaaagtatccaaaagcacc-3'. Glutathione peroxidase (Gpx) (160 bp) forward 5'-catgaccgaccccaagtaca-3', reverse 5 '-gggttgctaggctgcttgga-3'. Data were normalized for the content of actin mRNA.

\section{Statistical analyses}

Results are presented as the mean \pm s.E.M. of data obtained in at least three separate experiments. In some cases, data were normalized and expressed as per cent of control because of the variability of fluorescence readings among different repeat experiments due to differences in cell number, batch number and passage number of cultured cells, and as a consequence of differences among human sources. Data were analyzed by Student's $t$-test for unpaired samples or ANOVA.

\section{Results}

\section{Insulin increases death of MIN6 cells}

An earlier study showed that insulin (100 nM for $24 \mathrm{~h}$ ) decreased viability of RinM cells, and increased the effect of $\mathrm{H}_{2} \mathrm{O}_{2}$, as determined by increased $\mathrm{LDH}$ release (Sampson et al. 2010). In initial experiments on MIN6

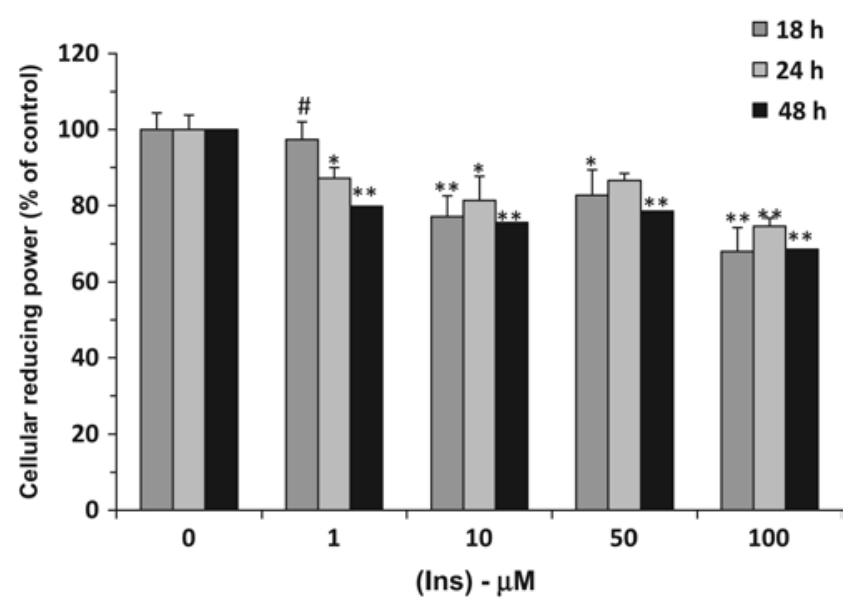

Figure 1

High concentrations of insulin induce dose- and time-related decreases in cellular reducing power of MIN6 cells. MIN6 cells were plated at a density of $3-4 \times 105 / \mathrm{mL}$ in 96 -well plate $(0.1 \mathrm{~mL} /$ well $)$ and then treated with insulin at the designated times with various concentrations. Cellular reducing power was determined as described in the 'Materials and methods' section. Each bar represents the mean \pm S.E.M. of replicate ( 3 or more) values obtained in three experiments $(* P<0.01, * * P<0.001$ vs untreated; \#not significant).

cells, we examined the effects of 1-300 nM insulin, given over a period of $4-48 \mathrm{~h}$, on cell viability as measured by Cellular Reducing Power (Beck et al. 2011). We found that insulin caused a dose- and time-dependent decrease in cellular reducing power, with maximum effects most consistently occurring with an insulin concentration of $100 \mathrm{nM}$ administered to the cells for $24 \mathrm{~h}$ (Fig. 1). Similarly, $\mathrm{H}_{2} \mathrm{O}_{2}$ in the range of $25-100 \mu \mathrm{M}$, given for $24 \mathrm{~h}$, induced a significant increase in cell death (as measured by LDH release). These concentrations of $\mathrm{H}_{2} \mathrm{O}_{2}$ are in accord with those used in other studies on pancreatic $\beta$ cells (Mehmeti et al. 2014, Wali et al. 2014, Fu et al. 2015, Lortz et al. 2015). Accordingly, in subsequent studies, we examined effects of $100 \mathrm{nM}$ insulin and $50-100 \mu \mathrm{M} \mathrm{H}_{2} \mathrm{O}_{2}$ given for $24 \mathrm{~h}$.

Similar to their effects on RinM cells, Fig. 2A shows that $24 \mathrm{~h}$ incubation of MIN6 cells with insulin $(100 \mathrm{nM})$ or $\mathrm{H}_{2} \mathrm{O}_{2}(50 \mu \mathrm{M})$ significantly increased $\mathrm{LDH}$ release. Insulin increased LDH release by nearly 2.7 -fold, compared with control untreated cells, while $50 \mu \mathrm{M} \mathrm{H} \mathrm{H}_{2} \mathrm{O}_{2}$ increased LDH release four-fold. Moreover, the effects of insulin and $\mathrm{H}_{2} \mathrm{O}_{2}$ in combination were greater than their individual effects and reached the levels of LDH release in the presence of the positive control Triton-X-100. We also examined the effects of insulin and $\mathrm{H}_{2} \mathrm{O}_{2}$, alone and in combination on cell viability as assessed by the Cell Titer Blue assay. In accord with its effects on LDH release, 
A

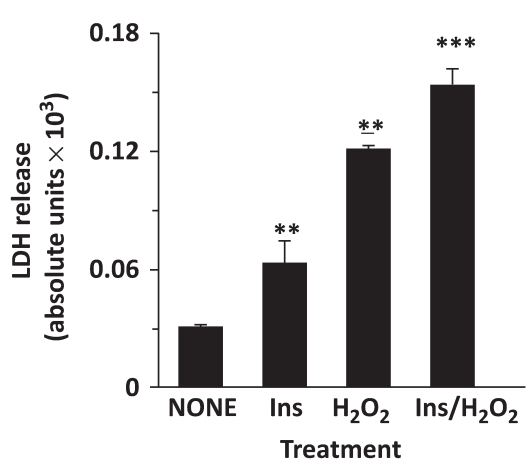

C

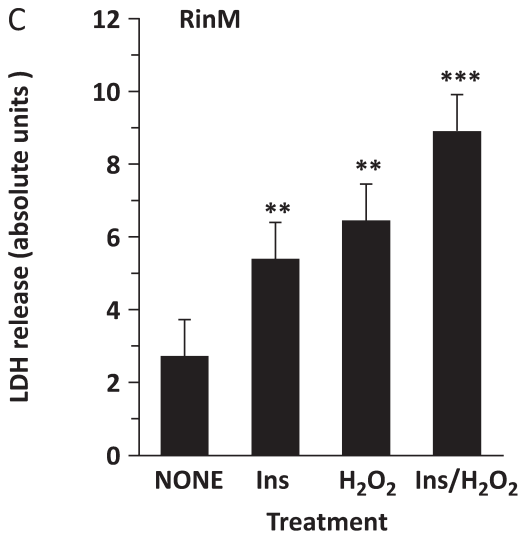

B

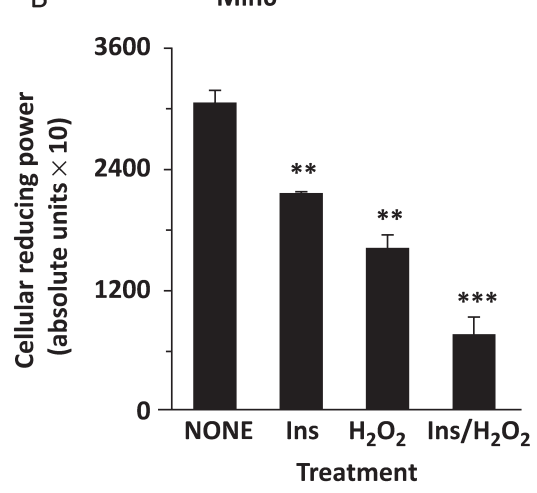

D 1500

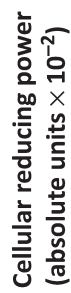

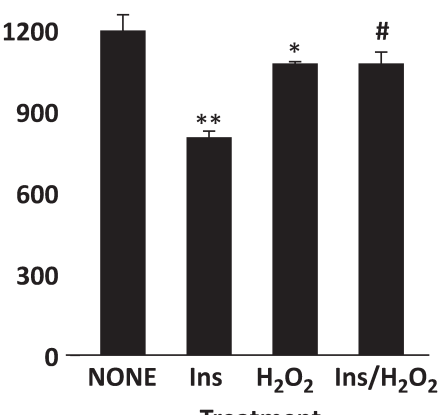

Figure 2

Insulin increases cell death, and augments $\mathrm{H}_{2} \mathrm{O}_{2}$-induced cell death in pancreatic $\beta$ cells. Cells were plated at a density of $3-4 \times 105 / \mathrm{mL}$ in 96-well plate $(0.1 \mathrm{~mL} /$ well). After $16 \mathrm{~h}$ incubation in serum and glucose-free medium, cells were treated with $\mathrm{H}_{2} \mathrm{O}_{2}(50 \mu \mathrm{M})$ or insulin $(100 \mathrm{nM})$, alone or in combination for $24 \mathrm{~h}$. (A) LDH release from MIN6 cells. (B) Viability of MIN6 cells measured by CTB reagent. (C) LDH release from RINm cells. (D) Viability of Ins 1 cells measured by CTB reagent. Results are mean \pm S.E.M. of replicate ( 3 or more) values obtained in three to four experiments $\left({ }^{*} P<0.01,{ }^{*} * P<0.001\right.$ vs untreated; $* * * P<0.01, \mathrm{H}_{2} \mathrm{O}_{2}+$ Ins vs $\mathrm{H}_{2} \mathrm{O}_{2}$ alone).
A
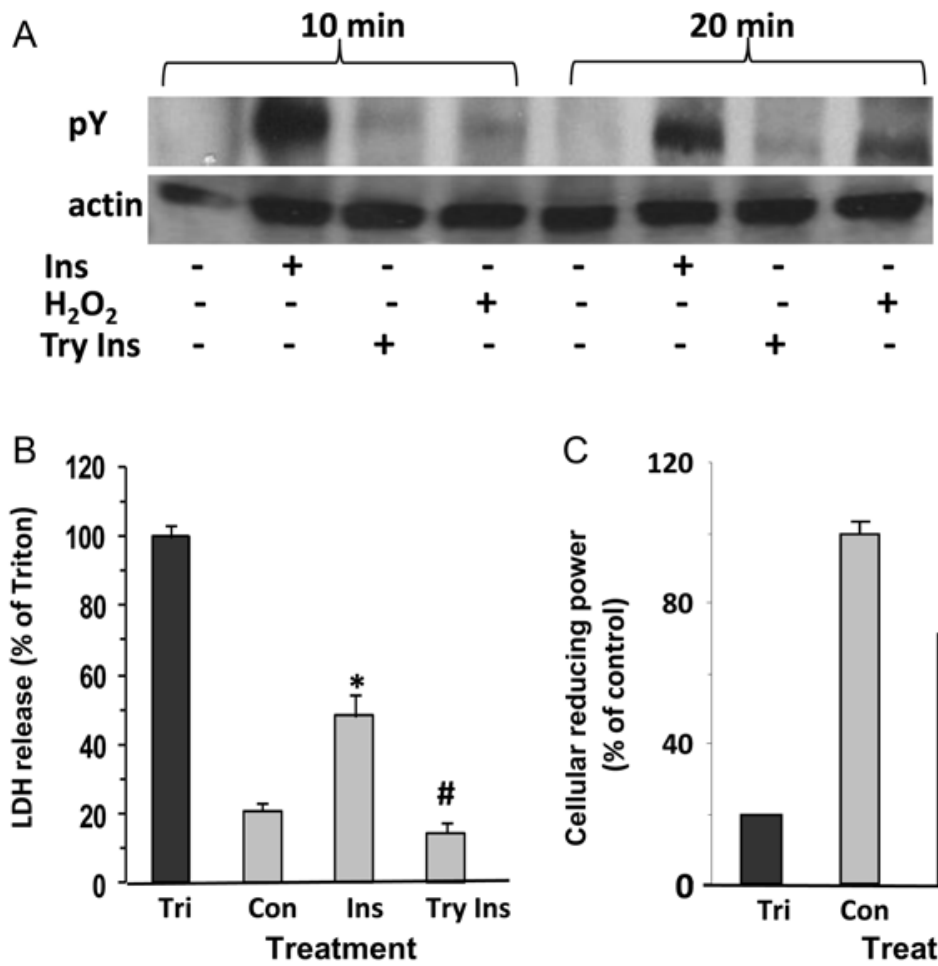

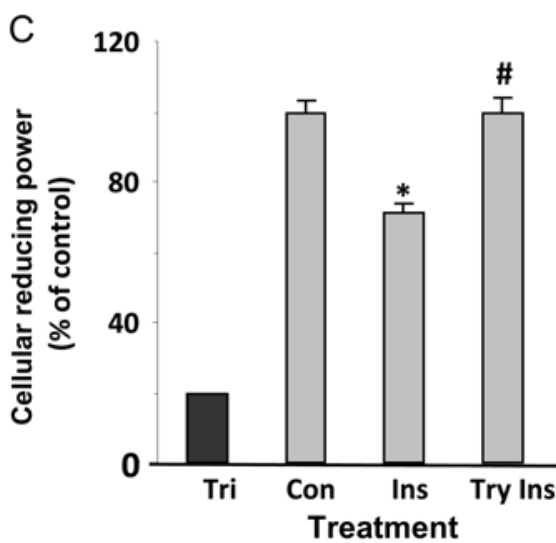

Figure 3

Incubation of insulin with trypsin $(0.25 \%$, 12-20h) eliminates effects of insulin on IR phosphorylation (A) LDH release (B) and cellular reducing power $(C)(A)$ Western blot showing elimination of insulin-induced phosphorylation of IR in $\mathrm{CHO}$ cells over expressing IR by incubation of insulin with $0.25 \%$ trypsin (Tr-Ins) for $12-20 \mathrm{~h}$ before addition to the cultures. Cells were plated at a density of $3-4 \times 10^{5} / \mathrm{mL}$. Treatment of cells, immunoprecipitation and Western blotting were done as described in the 'Materials and methods' section. The blot is representative of results obtained in three separate experiments. (B and C) MIN6 cells were plated and treated with insulin as described in the 'Materials and methods' section. Triton $\times 100$ (Tri) was administered as a control for maximum effects on LDH release and viability. Each bar represents the mean \pm S.E.M. of data obtained in three experiments $\left({ }^{*} P<0.01\right.$, $\# P$ NS vs untreated). http://joe.endocrinology-journals.org DOI: 10.1530/JOE-15-0505
๑) 2016 Society for Endocrinology Printed in Great Britain 
prolonged insulin treatment of MIN6 cells decreased their cellular reducing power (viability) by $20 \%$ when compared with untreated control cells, and augmented the reduction in cellular reducing power induced by $\mathrm{H}_{2} \mathrm{O}_{2}$ (Fig. 2B). We also confirmed these effects on RINm cells (Fig. 2C) and further obtained comparable results on additional pancreatic $\beta$ cell line (Ins1E cells; Fig. 2D). In the latter case, however, insulin did not potentiate the effects of $\mathrm{H}_{2} \mathrm{O}_{2}$. Preincubation of insulin with trypsin $(0.25 \%)$ for $12-20 \mathrm{~h}$ eliminated, as expected, insulininduced Tyr phosphorylation of the insulin receptor in $\mathrm{CHO}$ cells (Fig. 3A) and abrogated the effects of insulin on LDH release and cellular reducing power in MIN6 cells (Fig. 3B and C), suggesting that it is insulin per se that mediates these effects. Given that insulin is secreted by MIN6 cells, we measured the ambient insulin concentration in the conditioned media of these cells. Cells were treated with 1,10 and $100 \mathrm{nM}$ insulin for $24 \mathrm{~h}$. The insulin concentration in the media of control cells after $24 \mathrm{~h}$ was approximately $32 \mathrm{nM}$. In $24 \mathrm{~h}$ insulintreated cells, the insulin concentration did not increase on exposure to $1 \mathrm{nM}$ and increased to $41 \mathrm{nM}$ and $135 \mathrm{nM}$ when incubated with 10 and $100 \mathrm{nM}$ insulin, respectively. These findings suggest that the MIN6 cells were exposed to somewhat higher ambient insulin concentrations than those that were added exogenously.

\section{Insulin decreases cellular reducing power of isolated mouse and human islets}

To further validate the physiological significance of the above findings, we examined the effects of insulin on cellular reducing power of murine and human pancreatic islets. Twenty-four hours after isolation, mouse islets were treated with insulin $(100 \mathrm{nM})$ or $\mathrm{H}_{2} \mathrm{O}_{2}(25 \mu \mathrm{M})$, alone or in combination, and cellular reducing power was measured after an additional $24 \mathrm{~h}$. Figure $4 \mathrm{~A}$ shows that insulin decreased the cellular reducing power of mouse islets to $58 \pm 2 \%$ of untreated, control islets, while $\mathrm{H}_{2} \mathrm{O}_{2}$ decreased the reducing power of murine islets to $8 \%$. Combined treatment further decreased the islets' reducing power. Thus, the effects of insulin on viability of primary mouse islets were similar to those obtained with the pancreatic $\beta$ cell lines. As a further confirmation, experiments were conducted on isolated human pancreatic islets. Treatment of either intact or dispersed human islets with $10 \mathrm{nM}$ insulin for $24 \mathrm{~h}$ decreased their reducing power by $15-25 \%$ (Fig. 4B). The lower insulin concentration suggests that human islets may be more sensitive than mouse islets to these effects of insulin.
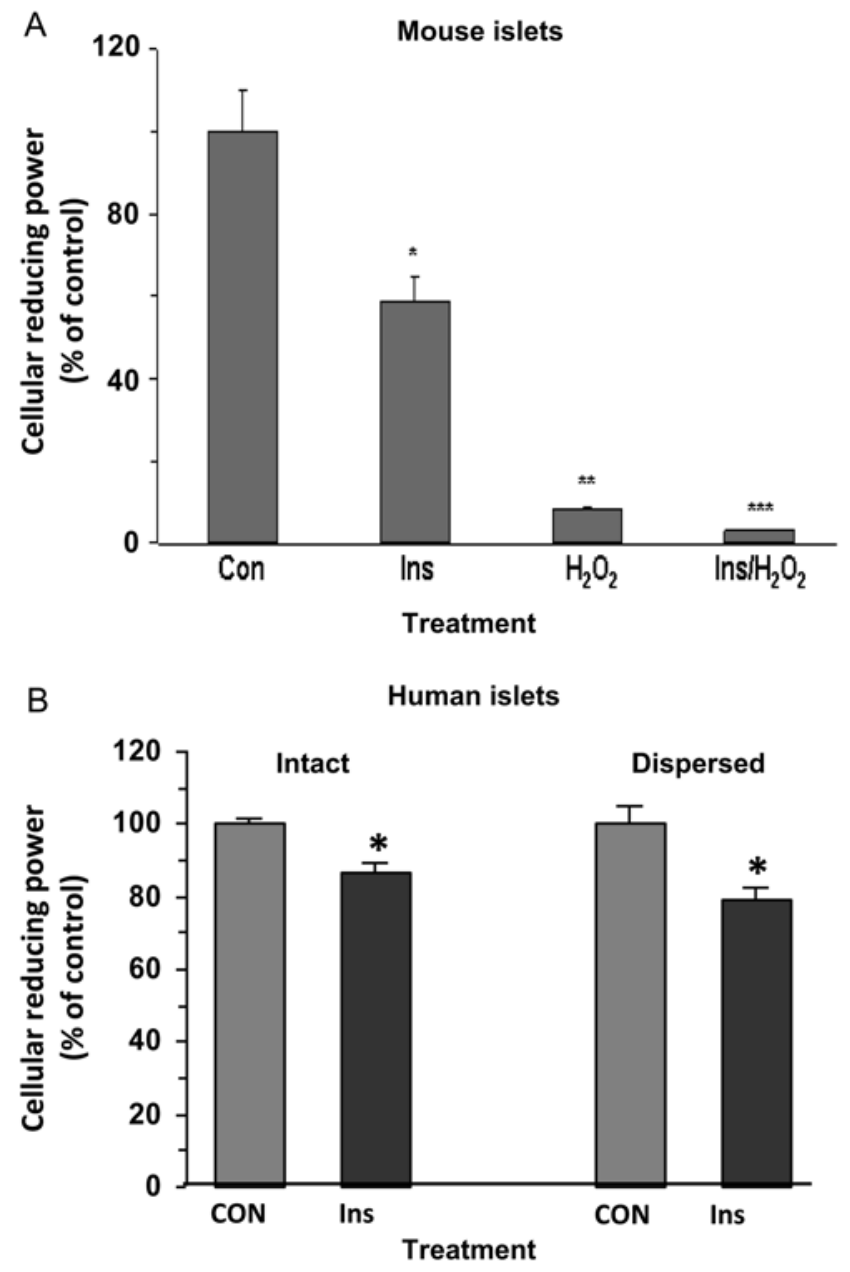

Figure 4

Insulin decreases the reducing power and augments the effect of $\mathrm{H}_{2} \mathrm{O}_{2}$ on isolated mouse and human pancreatic islets. (A) Mouse islets. Twenty-four hours after isolation, 10 islets per well were plated in 384-well plates and were treated with insulin $(100 \mathrm{nM})$ or $\mathrm{H}_{2} \mathrm{O}_{2}(50 \mu \mathrm{M})$, alone or in combination for $24 \mathrm{~h}$. Islets' reducing power was then measured using the CTB reagent. Results are mean \pm s.E.M. of replicate ( 3 or more) values obtained in three experiments $(* P<0.01, * * P<0.001$ vs control; $* * * P<0.01$ $\mathrm{H}_{2} \mathrm{O}_{2}$ /Ins vs $\mathrm{H}_{2} \mathrm{O}_{2}$ alone). (B) Human pancreatic islets. Intact or dispersed human islets were incubated in CMRL1066 medium containing $10 \%$ FBS (see the 'Materials and methods' section) for $24 \mathrm{~h}$, following which they were treated with insulin $(10 \mathrm{nM})$ for an additional $24 \mathrm{~h}$. Cellular reducing power was measured by the CTB reagent. Results are mean \pm S.E.M. of replicate $\left(3\right.$ or more) values obtained in three experiments $\left({ }^{*} P<0.01\right)$.

\section{Insulin promotes caspase activity in MIN6 cells and human islets}

To determine whether the reduction in cellular reducing power induced by insulin might be associated with increased apoptosis, we assayed caspase 3/7 activity in untreated and insulin-treated cells. As shown in Fig. 5A, treatment of MIN6 cells with insulin for 16-24h increased caspase activity by $70 \%$. A more moderate, still significant, increase could be detected in intact human

Published by Bioscientifica Ltd. 
A

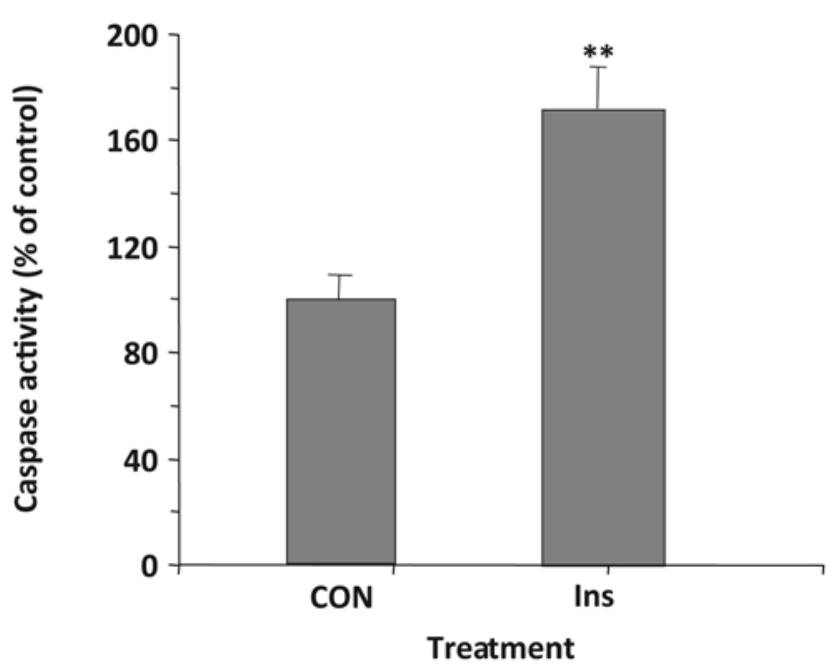

B

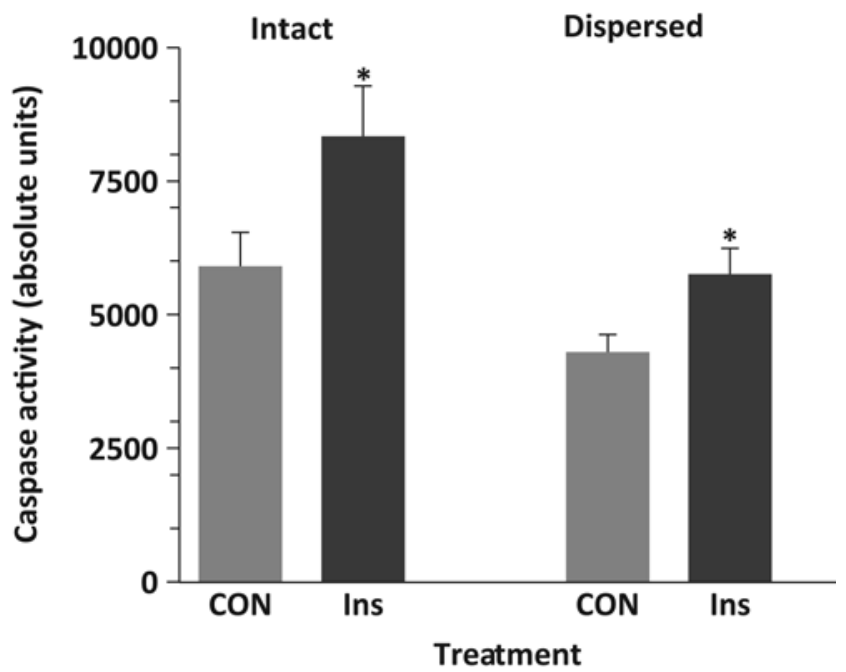

Figure $\mathbf{5}$

Insulin increases caspase 3/7 activity in MIN6 cells and human pancreatic islets. MIN6 cells (A) and intact and dispersed human islets (B) were grown and treated for $16 \mathrm{~h}$ with insulin (MIN6 cells $100 \mathrm{nM}$; islets (10 nM) as described. At the end of incubation, apoptosis was assayed by caspase-3/7 activity. Results are mean \pm S.E.M. of replicate values obtained in independent experiments ( 3 experiments for MIN6 cells and intact islets; 2 experiments on dispersed human islets) $(* P>0.05, * * P<0.01)$.

islets (Fig. 5B) and the same trend was observed even in dispersed human islets.

We next examined whether the increase in caspase activity might be linked to insulin's effects on cellular reducing power. To accomplish this, we treated MIN6 cells with insulin $(100 \mathrm{nM})$ in the presence or absence of the caspase inhibitor z-VAD-fmk $(20 \mu \mathrm{M})$ for $24 \mathrm{~h}$. Figure $6 \mathrm{~A}$ shows that insulin significantly increased caspase $3 / 7$ activity compared with untreated control cells, and this

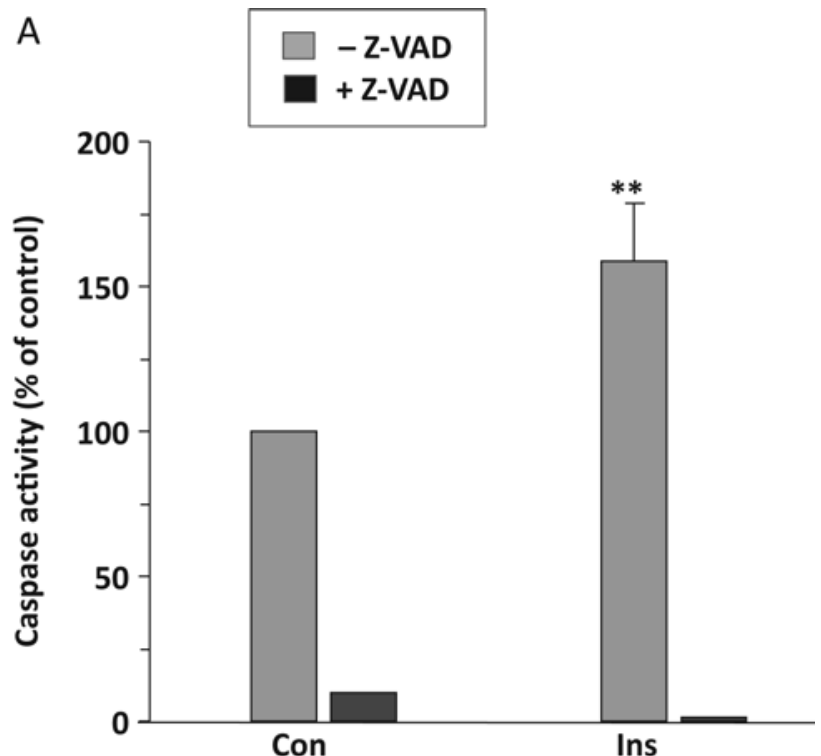

B

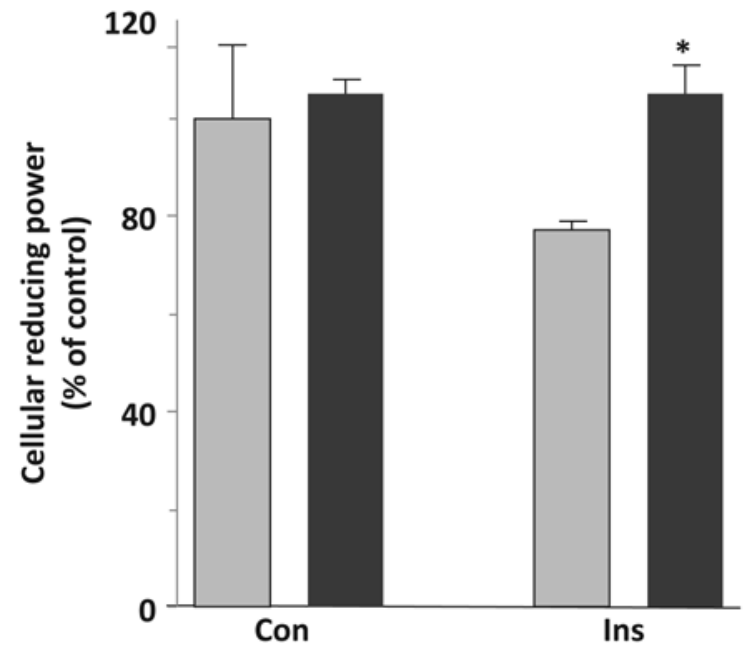

Figure 6

Z-VAD abrogates insulin-induced increase in caspase activity and the decrease in reducing power of MIN6 cells. MIN6 cells were grown as described in Fig. 1 and were treated with insulin $(100 \mathrm{nM})$ or insulin and Z-VAD $(25 \mu \mathrm{M})$ for $24 \mathrm{~h}$. Following treatment, measurements were made of caspase activity (A) and cellular reducing power (B) as described in Methods. Results are mean \pm S.E.M. of replicate (4 or more) values obtained in three to four experiments $\left({ }^{*} P<0.05 ; * * P<0.01\right)$.

effect of insulin was abrogated by z-VAD-fmk. Similarly, z-VAD-fmk eliminated the $23 \%$ reduction in cellular reducing power caused by insulin treatment (Fig. 6B).

We also investigated the effects of insulin on cytokine-induced decrease in $\beta$ cell viability and increase in caspase activity. MIN6 cells were treated with insulin $(100 \mathrm{nM})$ or a cytokine mixture $(3 \mathrm{nmol} / \mathrm{L} \mathrm{TNF} \alpha, 3 \mathrm{nmol} / \mathrm{L}$

Published by Bioscientifica Ltd 
A

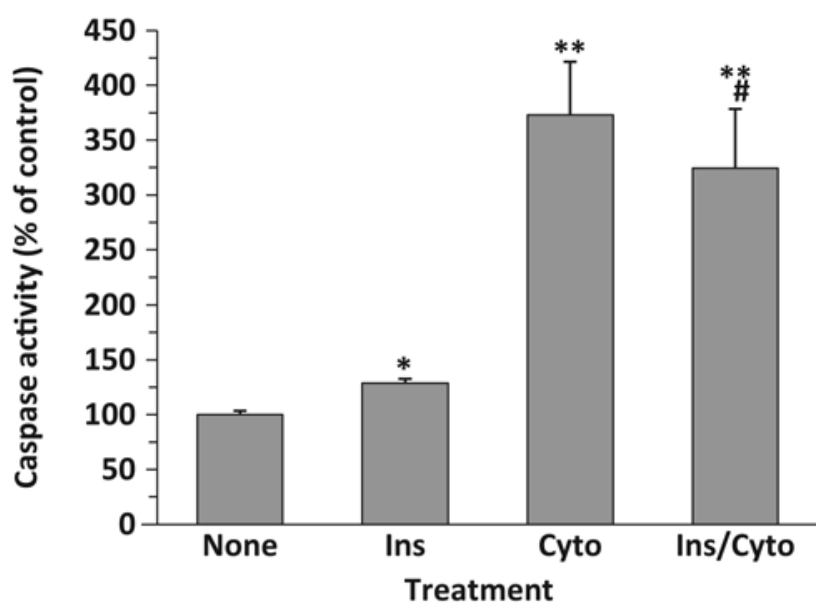

B

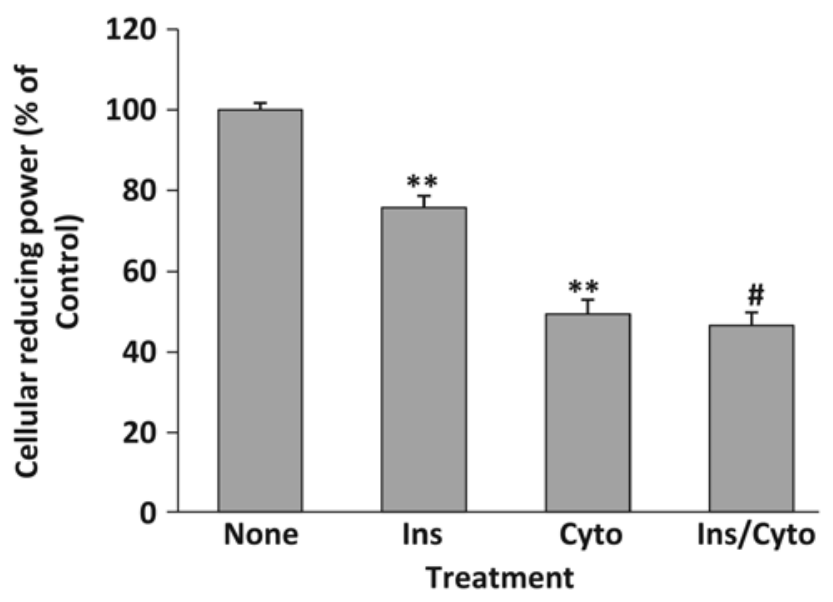

Figure 7

Insulin does not increase the effects of cytokines on cellular reducing power or caspase activity. Cells were plated as in Fig. 1 and treated with insulin ( $100 \mathrm{nM}$ ) or cytomix ( $3 \mathrm{nmol} / \mathrm{L} \mathrm{TNF} \alpha, 3 \mathrm{nmol} / \mathrm{L} \mathrm{IFN}-\gamma$ and $1.5 \mathrm{nmol} / \mathrm{L}$ $\mathrm{IL}-1 \beta)$, alone and in combination for $24 \mathrm{~h}$. At the end of incubation, apoptosis was assayed by caspase- $3 / 7$ activity $(A)$ and cellular reducing power using the CTB reagent (B). Each bar represents the mean \pm S.E.M. of 4-6 replicates samples in each of 4 independent experiments. $\left(A:{ }^{*} P<0.01\right.$ Ins vs Cyto; ${ }^{*} P<0.01$ cyto and Ins/cyto vs none; \#not significant Ins/cyto vs Ins. B: ${ }^{*} P<001$, Ins and cyto vs none; \#not significant cyto vs Ins/cyto; see text for further details.

IFN- $\gamma$ and $1.5 \mathrm{nmol} / \mathrm{L}$ IL-1 $\beta$; (Beck et al. 2013)), alone and in combination for $24 \mathrm{~h}$. As shown in Fig. 7A, insulin induced a small yet significant increase in caspase activity, while cytokines induced a much bigger effect, yet the effect of the two administered in combination was not significantly different from cytokine treatment alone. Similarly, both insulin and cytokine mix each caused a significant decrease in cellular reducing power with the cytokine mix having a greater effect (Fig. 7B). Here again, a combined treatment for $24 \mathrm{~h}$ with both insulin and cytokines did not further decrease the effect of cytokines on viability.

\section{The insulin-induced increase in cell death and caspase activity is selective for $\beta$ cells}

We reported that insulin increased LDH release from RINm and RINm5F pancreatic $\beta$ cell lines but not from nonpancreatic $\beta$ cells such as PC12 (rat pheochromocytoma) or AML-12 (mouse liver) cells (Sampson et al. 2010). To further verify these findings, we examined the effects of insulin on cellular reducing power and LDH release from three additional non- $\beta$ cell lines HEK-293 cells, as well as CHO cells and NIH fibroblasts that overexpress human IR (CHO-T and NIH-T cells). In each of these cell lines, insulin, unlike $\mathrm{H}_{2} \mathrm{O}_{2}$, neither induced $\mathrm{LDH}$ release nor affected their reducing power (Fig. 8A, B, C and D). Indeed, insulin actually decreased LDH release from HEK293 cells.

The various nonpancreatic $\beta$ cell lines so far studied are not classical insulin target cells; therefore, we performed additional experiments on a liver cell line (human liver carcinoma cells HepG2) that is considered a common insulin target and is used in numerous studies on IR signaling (Hah et al. 1992, Fawcett et al. 2001, Patel et al. 2004, Biswas et al. 2007). HepG2 cells were treated with insulin $(100 \mathrm{nM})$ or a cytokine mixture alone or in combination for $24 \mathrm{~h}$ (as done for MIN6 cells) and measurements of caspase activity and cell reducing power were then made. As shown in Fig. 9A, caspase activity of HepG2 cells was slightly increased by insulin and even more so by cytokines. Moreover, the simultaneous treatment of HepG2 cells with both cytokines and insulin caused an increase in caspase activity greater than that by either substance alone. In contrast, cellular reducing power of HepG2 cells (Fig. 9B) was not significantly altered by either insulin or cytokines. Combined treatment, however, did cause a slight but significant reduction in cellular reducing power, albeit not as strongly as might have been expected from the effects on caspase activity.

We also examined the cellular content of MCL-1, a family member of the BCL-2 proteins that regulates cell survival in response to extracellular signals (Allagnat et al. 2011) in both MIN6 and HepG2 cells. As shown in Fig. 10A and C (black bars), MCL-1 protein levels in MIN6 cells were reduced as early as $2 \mathrm{~h}$ following treatment with insulin, and this effect persisted for up to $24 \mathrm{~h}$. In contrast, and consistent with its effects on HepG2 cell viability, insulin 
A
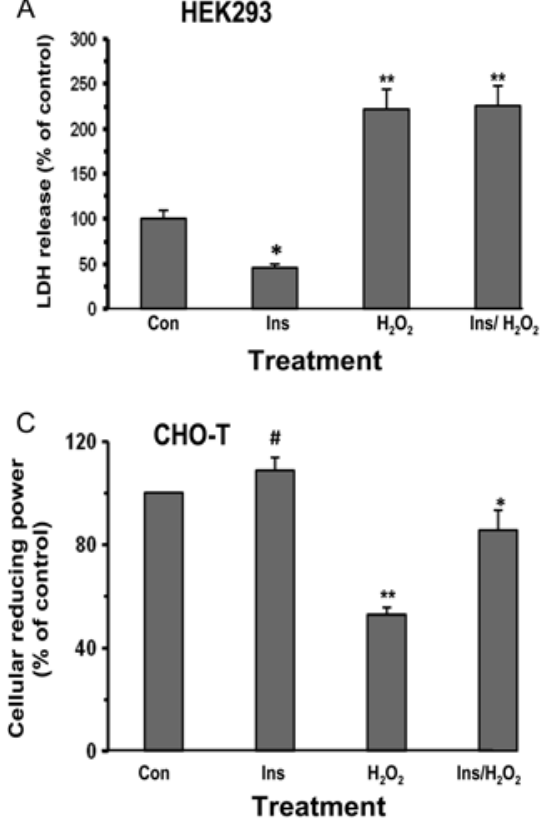
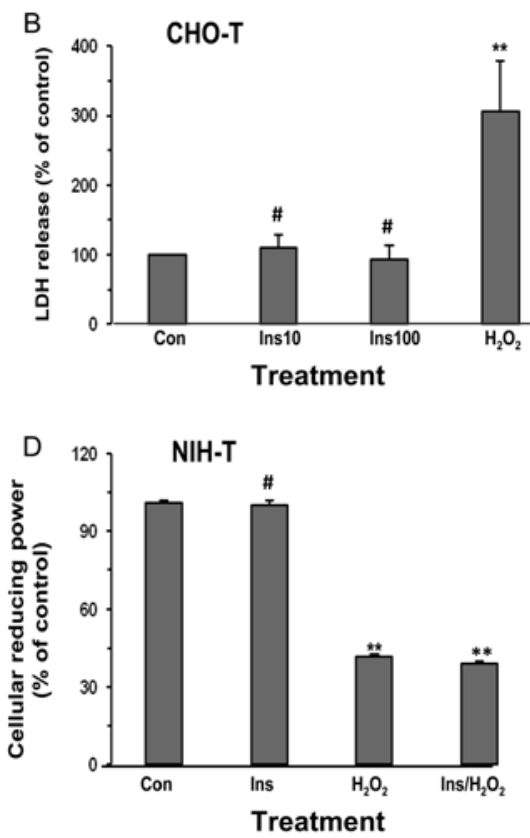

Figure 8

Insulin does not induce LDH release and does not affect the reducing power of nonpancreatic cells. Cells were plated as in Fig. 1 and, after $16 \mathrm{~h}$ incubation were treated with $\mathrm{H}_{2} \mathrm{O}_{2}(50 \mu \mathrm{M})$ or insulin $(100 \mathrm{nM})$, alone or in combination, for an additional $24 \mathrm{~h}$. (A) LDH release from T-293 cells; (B) LDH release from CHO-T cells, cellular reducing power of CHO-T cells (C) or NIH-T cells (D). Results are mean \pm S.E.M. of replicate (3 or more) values obtained in three to four experiments $\left({ }^{*} P<0.01,{ }^{*} P<0.001\right.$ vs untreated), \#not significant Ins vs con. had no detectable effect on MCL-1 protein levels in HepG2 cells (Fig. 10B and C-gray bars). These results collectively indicate that insulin may act selectively on pancreatic $\beta$ cells to prime a decrease in their viability, whereas it has an apparently minor role in nonpancreatic $\beta$ cells.

\section{Insulin increases ROS production in MIN6 cells}

Among the possible mediators of insulin-induced increase in cell death are ROS and NO, which have been shown to be deleterious to $\beta$ cell viability (Konishi et al. 1997, Nakamura et al. 2006, Hou et al. 2008, Sampson et al. 2010, Bedoya et al. 2012, Broniowska et al. 2014). Moreover, insulin was shown to increase ROS release in several cell types (Mahadev et al. 2001, Goldstein et al. 2005a,b, Biswas et al. 2007, Guichard et al. 2008), including RINm (rat) pancreatic $\beta$-cells (Sampson et al. 2010). Little appears to be known regarding the effects of insulin on NO release. To address this possibility, we studied the effects of insulin on iNos transcription and NO production. As shown in Fig. 11A, exposure of MIN6 cells to insulin for 24-48 h induced only a slight 1.5-2.0-fold increase in iNos expression, but not in NO production (not shown). In contrast, we could show that the treatment of MIN6 cells with $100 \mathrm{nM}$ insulin for $18 \mathrm{~h}$ resulted in generation of ROS, as indicated by a significant accumulation of the fluorescent oxidized product (DCEH-DA, see the 'Materials and methods' section) (Fig. 11B). Quantification of the cellular fluorescent intensity revealed that insulin induced a 50\% increase in ROS production, when compared with control untreated cells; $\mathrm{H}_{2} \mathrm{O}_{2}$ induced an approximately two-fold increase, while a combined treatment with insulin and $\mathrm{H}_{2} \mathrm{O}_{2}$ significantly increased ROS production approximately three-fold (Fig. 11C). In contrast, insulin did not increase ROS levels in CHO-T cells, either when added alone or in combination with $\mathrm{H}_{2} \mathrm{O}_{2}$ (Fig. 11D). We were also able to confirm earlier findings (Sampson et al. 2010) that insulin-induced ROS generation is abrogated by $\mathrm{N}$-acetyl cysteine (not shown).

\section{Insulin does not appear to directly affect antioxidative enzyme expression}

Our results indicate that ROS generated by pancreatic $\beta$ cells in response to high concentrations of insulin may contribute to the deleterious effect of insulin on $\beta$ cell viability. The generation of ROS might be expected to increase the relatively low expression of antioxidant enzymes. Alternatively, it is possible that insulin might directly alter the expression of these enzymes. Accordingly, we examined MIN6 cells for the effects of $100 \mathrm{nM}$ insulin given for 24 and $48 \mathrm{~h}$ on expression of Sod1, Sod2, Cat and Gpx, which are the main antioxidant enzymes in pancreatic $\beta$ cells (Laybutt et al. 2002, Chetboun et al. 2012, Bhakkiyalakshmi et al. 2014, Liu et al. 2015). As shown in Fig. 12, the expressions of Sod1 and Sod2 were not significantly altered after either 24 or $48 \mathrm{~h}$ insulin exposure. In contrast, Cat and Gpx expressions were increased after both 24 and $48 \mathrm{~h}$ insulin treatment. 

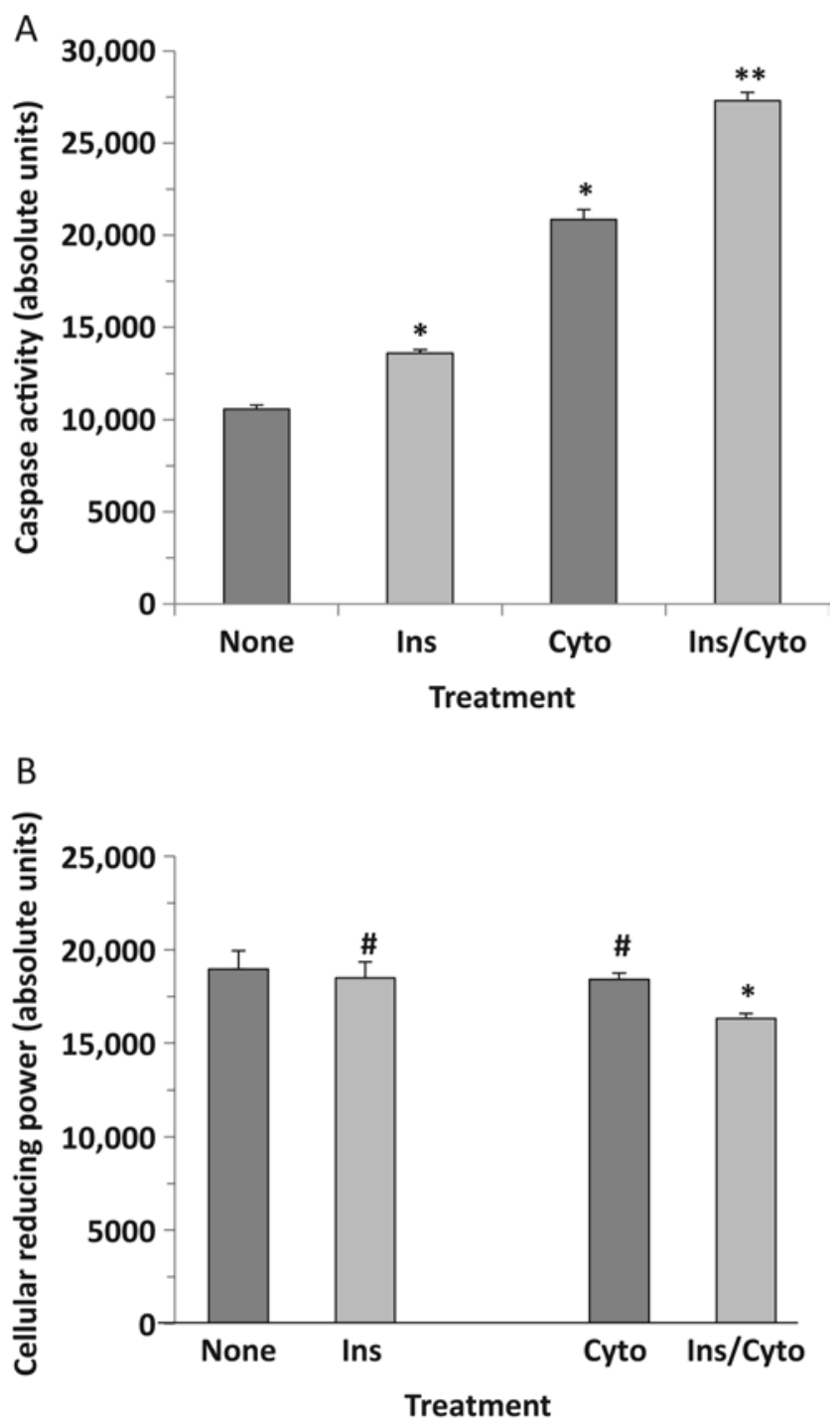

Figure 9

Insulin increases caspase 3/7 activity but only slightly affects cellular reducing power of HepG2 cells. HepG2 cells were grown in 96-well plates as described in the 'Materials and methods' section and treated with insulin (100 nM) or cytomix ( $3 \mathrm{nmol} / \mathrm{L} \mathrm{TNF} \alpha, 3 \mathrm{nmol} / \mathrm{L} \mathrm{IFN}-\gamma$ and $1.5 \mathrm{nmol} / \mathrm{L}$ IL-1 $\beta$ ), alone and in combination for $24 \mathrm{~h}$. At the end of incubation, apoptosis was assayed by caspase-3/7 activity (A) and cellular reducing power using the CTB reagent (B). Each bar represents the mean \pm s.E.M. of four to six replicate samples in each of three independent experiments. (A: ${ }^{*} P<0.001$ Ins vs none; ${ }^{*} P<0.01$ Ins/cyto vs Ins. $B$ : $\#$ not significant none vs Ins and none vs cyto; ${ }^{*} P<0.01$ Ins/cyto vs Ins). See text for further details.

\section{Insulin induces changes in expression of ER stress genes}

Excess accumulation of ROS in pancreatic $\beta$ cells induces both oxidative and endoplasmic reticulum (ER) stress, which triggers the unfolded protein response (UPR) (Vanderford 2010) which may lead, if sustained, to $\beta$-cell dysfunction and apoptosis (Kitiphongspattana et al. 2007, Lin et al. 2012). To examine whether insulin might alter
A

Min6

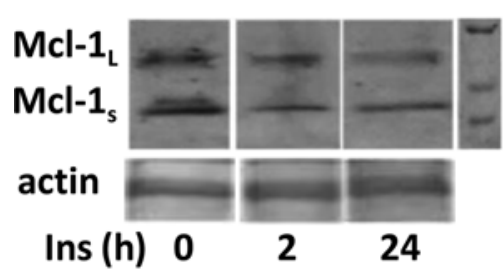

B HepG2

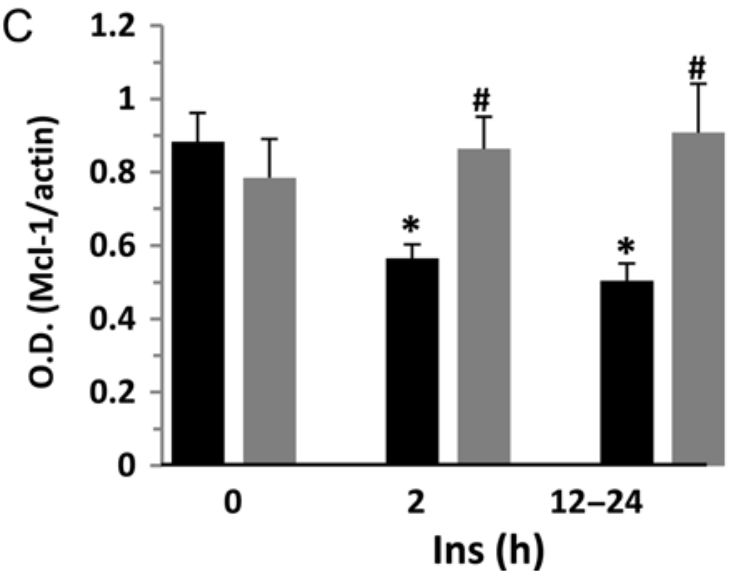

Figure 10

Insulin downregulates Mcl-1 protein in MIN6 but not HepG2 cells. MIN6 and HepG2 cells were grown and treated with insulin for the designated times. (A and B) Western blots showing levels of Mcl-1 in MIN6 and HepG2 cells. (C) Graph of densitometry measurements of $\mathrm{Mcl}-\mathrm{I}_{1}$ relative to actin levels following treatment of MIN6 cells with insulin for the designated times (black bars - MIN6; gray bars - HepG2). Each bar represents the mean \pm S.E.M. of measurements made of Western blots in six independent experiments. In two of these experiments, measurements were made after $12 \mathrm{~h}$. These values were pooled with the $24 \mathrm{~h}$ data. $\left({ }^{*} P<0.05 ;{ }^{* N S}\right)$.

expression of UPR-associated genes, we determined the mRNA levels of Bip, Xbp1, Atf4 and Chop (Walter \& Ron 2011) in MIN6 cells treated with insulin for 24-48h. As shown in Fig. 13A, insulin significantly reduced the expression of Bip and Xbp1 (25 and 33\%, respectively), while it did not significantly affect the mRNA levels of Atf4 in MIN6 cells. In contrast, the expression levels of Chop were significantly increased (30\%) in the presence of insulin. Thus, insulin affected the expression of at least three UPR-associated proteins, which could be accounted for by its effects on ROS production in pancreatic $\beta$ cells. Hence, insulin alone or in combination with potentially deleterious factors may induce effects consistent with ER stress.

Among the candidate ER stress proteins that might be involved in insulin effects is Trb3, a downstream target of Atf4, which has been found to be increased by cytokines (Kanki et al. 2009, Humphrey et al. 2010, Kanwar 2010), 
A

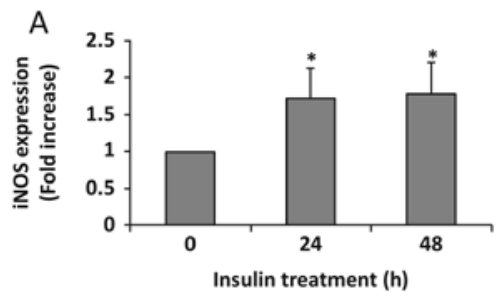

B

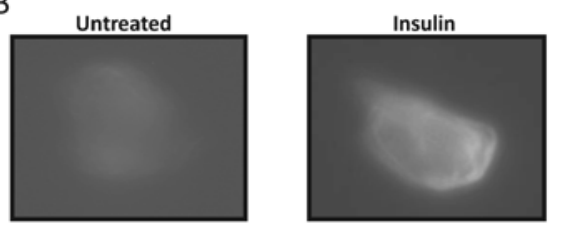

C

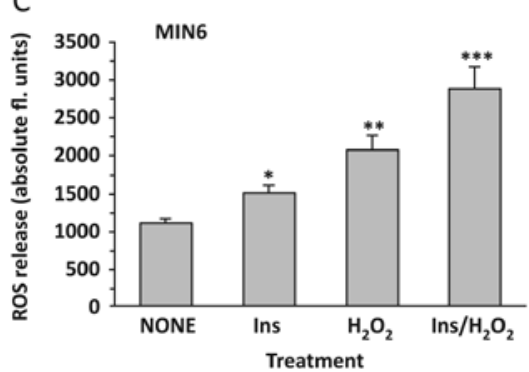

\section{Figure 11}

Insulin increases ROS production in MIN6 cells. MIN6 cells were plated at a density of $2.5-3 \times 105 / \mathrm{mL}$ in 12 -well plates and, after $16 \mathrm{~h}$ incubation, were treated with insulin ( $100 \mathrm{nM})$ for $24 \mathrm{~h}$. (A) mRNA levels of iNOS were determined by qRT-PCR as described in the 'Materials and methods' section, and were quantified following normalization to actin mRNA levels. (B) Representative photomicroscope images of DCF-DA accumulation in untreated and insulin-treated MIN6 cells. Accumulation was measured by an increase in florescence at $530 \mathrm{~nm}$ when the sample was excited at $485 \mathrm{~nm}$. (calibration line $=20$ microns). (C and D) Florescence measurements of CM-H2DCFDA (ROS release) in MIN6 (C) and CHO-T (D) cells. Cells were plated at a density of $5-6 \times 105 / \mathrm{mL}$ in 24-well plates (0.5 mL/well). After overnight incubation, CM-H2DCFDA (10 $\mu \mathrm{M})$ reagent was added to the cells as described in the 'Materials and methods' section. Two hours later, MIN6 and CHO-T cells were treated with insulin $(100 \mathrm{nM})$ or $\mathrm{H}_{2} \mathrm{O}_{2}(75 \mu \mathrm{M})$, alone or in combination, as indicated. Florescence was measured after treatment of $18 \mathrm{~h}$. Results are mean \pm S.E.M. of measurements obtained in three experiments ( $P_{<} 0.01$, $* * P<0.001$ vs untreated control cells; $* * * P<0.001, \mathrm{H}_{2} \mathrm{O}_{2}$ alone vs $\mathrm{H}_{2} \mathrm{O}_{2}+$ Ins; ${ }^{*}$ not significant Ins $/ \mathrm{H}_{2} \mathrm{O}_{2}$ vs $\mathrm{H}_{2} \mathrm{O}_{2}$ ).

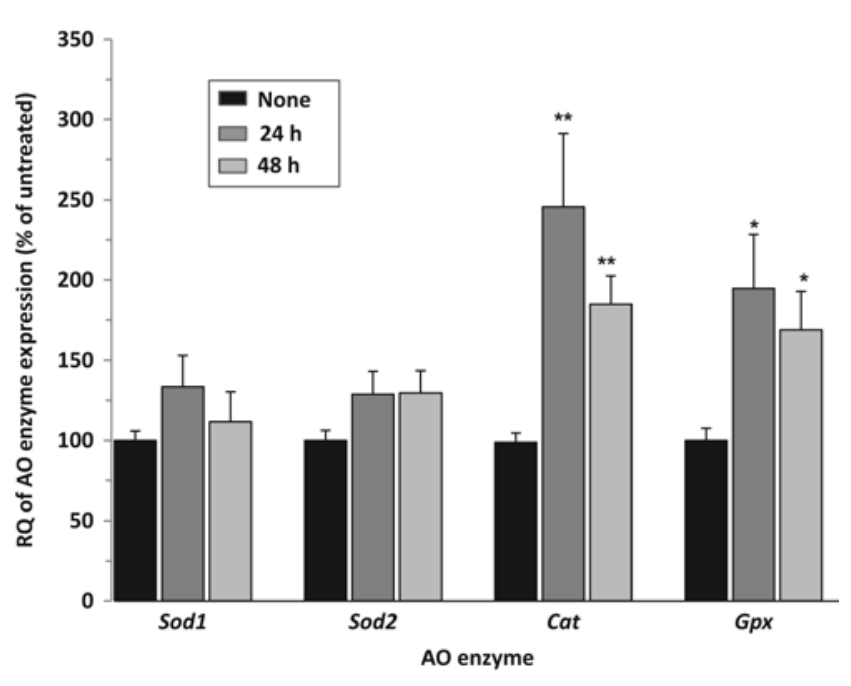

\section{Figure 12}

Insulin affects the expression of certain antioxidative enzyme. MIN6 cells were plated at a density of $2.5-3 \times 105 / \mathrm{mL}$ in 12 -well plates and, after $16 \mathrm{~h}$ incubation, were treated with insulin $(100 \mathrm{nM})$ for 24 and $48 \mathrm{~h}$. mRNA levels of the indicated genes were determined by qRT-PCR as described in the 'Materials and methods' section, and were quantified following normalization to actin mRNA levels. In all graphs, bars represent the mean \pm S.E.M. of duplicate determinations obtained in four separate experiments. Sod1 and Sod2, superoxide dismutase 1 and 2; Cat, catalase; Gpx, glutathione peroxidase. $\left({ }^{*} P<0.05 ; * * P<0.01\right.$. All other differences were not significant at $P<0.05)$. and by insulin in Fao rat hepatoma and in 3T3-L1 adipocytes (Du \& Ding 2009). Accordingly, we examined the effect of insulin on the expression of Trb3 in MIN6 cells. Exposure of MIN6 cells to insulin for $24-48 \mathrm{~h}$ induced a three-fold increase in the expression of $\operatorname{Tr} b 3$ (Fig. 13B). Given that insulin increases the effect of cytokines on caspase 3/7 activity in HepG2 cells (Fig. 9), we thought it of interest also to examine potential interaction between insulin and cytokines on Trb3 expression in MIN6 cells. In these experiments (Fig. 13C), we used a low concentration ( 0.1 to $0.25 \times$ ) of cytokine mix, which did not elicit a significant increase in Trb3 expression. When, however, cells were treated with low cytokine concentration together with insulin for $24-48 \mathrm{~h}$, Trb3 expression was approximately doubled. These data demonstrate that insulin is able to boost the effects of low cytokine concentrations on Trb3.

\section{Discussion}

Insulin resistance is a state in which target cells fail to respond to ordinary levels of insulin resulting in the need for increased levels of insulin to control plasma glucose levels. The cycle of hyperglycemia and hyperinsulinemia

Published by Bioscientifica Ltd 

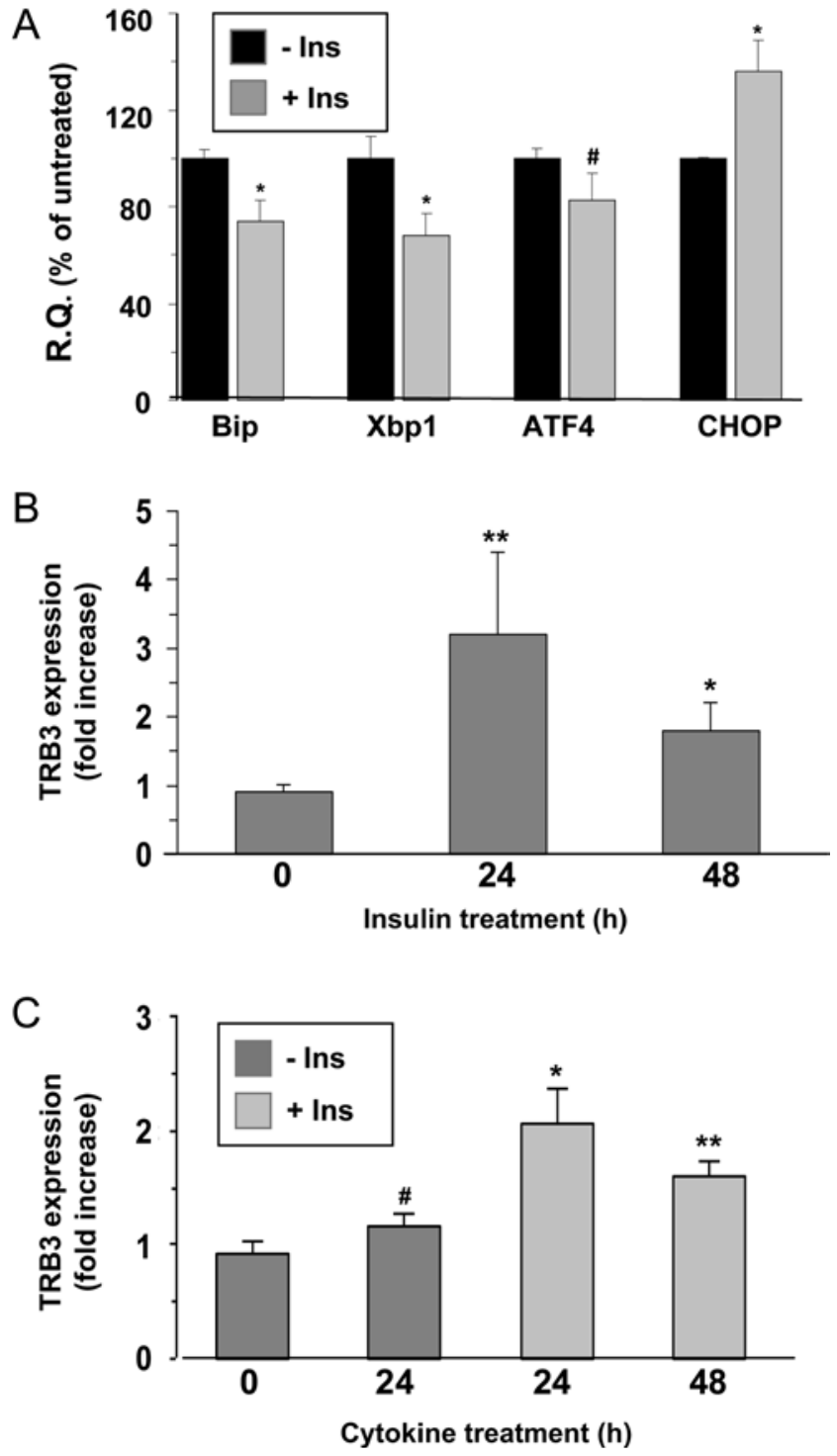

Figure 13

Insulin alters the expression of ER stress genes in MIN6 cells. MIN6 cells were plated at a density of $2.5-3 \times 105 / \mathrm{mL}$ in 12 -well plates and, after $16 \mathrm{~h}$ incubation, were treated with insulin $(100 \mathrm{nM})$ for $24 \mathrm{~h}$. mRNA levels of the indicated genes were determined by qRT-PCR as described in the 'Materials and methods' section, and were quantified following normalization to actin mRNA levels. (A) Insulin decreased the expression of Bip and Xbp1, and increased the expression of Chop. (B) Insulin increased Trb3 expression and (C) augmented the effect of cytomix to elevate $T r b 3$ expression. In all graphs, bars represent the mean \pm S.E.M. of data obtained in three to four separate experiments ( $A$ and $B * P<0.01$, $* * P<0.05$ insulin vs untreated; - \#not significant. $C$ - \#not significant, ${ }^{*} P<0.01, * * P<0.05$ insulin + cytokine mix vs cytokine mix alone).

eventually leads to pancreatic $\beta$ cell deterioration and death. In this study, we provide evidence that elevated levels of insulin itself might contribute an important component to the increased demise of $\beta$ cells, possibly attributable to insulin-induced production of ROS in $\beta$ cells, induction of ER stress-related genes and subsequent stimulation of apoptotic processes. Apoptosis may be an important mechanism of insulin-induced $\beta$ cell death, because insulin-induced changes in caspase 3/7 activity and cell viability were completely abrogated by z-VAD-fmk, a selective inhibitor of caspases. Hence, prolonged elevated levels of insulin may prime $\beta$ cell apoptosis and thereby exacerbate $\beta$-cell deterioration in response to other factors.

Several lines of evidence support this conclusion. First, we could show that prolonged $(24 \mathrm{~h})$ insulin treatment increased caspase activity, decreased the reducing power and promoted the release of LDH from three pancreatic $\beta$ cell lines (MIN6, RINm, INS-1) as well as isolated mouse and human islets. Human islets appeared to be more sensitive to the effects of insulin, as the decrease in cell viability and increase in caspase $3 / 7$ activity were readily detectable at an insulin concentration of $10 \mathrm{nM}$ in human islets compared with $100 \mathrm{nM}$ in mouse islets. This difference might be explained by the fragile state of human islets, as conditions for isolation and transportation were considerably more severe than those for mouse islets (see the 'Materials and methods' section). Insulin not only promoted death of pancreatic $\beta$ cells, but sustained insulin treatment also inhibited $\beta$-cell survival, as evidenced by the significant decrease in cellular content of MCL-1, a family member of the BCL antiapoptotic proteins, in $\beta$ cells subjected to prolonged insulin treatment. The insulin-induced increase in $\beta$ cell death was associated with elevated production of ROS that could result in increased ER stress. This idea is supported by our finding of a decrease in the expression of Bip, which triggers an unfolded protein response (UPR) (Walter \& Ron 2011). UPR involves the activation of three linked signal transduction pathways emanating from three principle ER stress sensors: IRE1 $\alpha$, double-stranded RNAdependent protein kinase-like kinase (PERK) and ATF6 $\alpha$ (Ron \& Walter 2007). Failure of the UPR to reduce the ER stress and resume homeostasis results in the initiation of an UPR-triggered apoptotic process (Walter \& Ron 2011). Indeed, we could show that insulin triggers induction of the UPR. We found an insulin-dependent reduced expression of $X b p 1$, presumably due to $X b p 1$ splicing (He et al. 2010), which contributes to a sustained UPR that leads to apoptosis (Walter \& Ron 2011). Sustained insulin treatment also increased the expression of $\operatorname{Tr} 33$ and its downstream target Chop, a key mediator of UPR-induced apoptotic process in $\beta$ cells (Vanderford 2010). The effect of insulin to increase Trb3 expression is in accord with a recent study in Fao hepatoma and 3T3 L1-adipocytes; indeed, insulin promoted the expression of several

Published by Bioscientifica Ltd 
stress-related genes in these cells similar to our findings in this study (Du \& Ding 2009). It still remains unclear why insulin did not affect the transcription of Atf4, the upstream regulator of $T r b 3$. Our results are thus in accord with a recent study showing that the balance between Xbp1-mediated adaptive and Chop-dependent apoptotic UPR is critically important for $\beta$-cell survival during ER stress (Chan et al. 2015).

Along with the generation of ROS, relatively longterm exposure of MIN6 cells to insulin did appear to increase significantly the expressions of the antioxidant enzymes Cat and Gpx, as occurs with some other inducers of cellular stress (Tiedge et al. 1997, Laybutt et al. 2002, Palsamy \& Subramanian 2010, Chetboun et al. 2012, Bhakkiyalakshmi et al. 2014, Tersey et al. 2014, Vasu et al. 2014, An et al. 2015). In contrast, the expressions of Sod1 and Sod2 were only slightly and not significantly increased by 24 and $48 \mathrm{~h}$ insulin exposure. Furthermore, we could not detect any significant interaction between cytokines and insulin on antioxidant enzymes expression (not shown). We would, therefore, propose that the effects on Cat and Glx were secondary to the generation of ROS, and that insulin itself has no direct effect on expression of these enzymes.

In addition to its effects as a mild inducer of $\beta$ cell death, insulin seems to increase $\beta$ cell death triggered by other stress inducers. Here, as well as in an earlier study (Sampson et al. 2010), we could show that insulin significantly increased caspase activity and LDH release, apparently triggered by $\mathrm{H}_{2} \mathrm{O}_{2}$, an inducer of oxidative stress. In addition, we found that insulin not only increased $T r b 3$ expression but also could increase the effect of subthreshold cytokine levels on Trb3 expression. Hence, prolonged insulin treatment potentiates detrimental effects of stress inducers on $\beta$ cell function. We suggest that these effects of insulin are most likely due in part to its own effects on ROS production and the UPR.

In contrast to its positive interaction with $\mathrm{H}_{2} \mathrm{O}_{2}$, insulin did not significantly influence the effects of cytokines on cell viability and caspase activity. One possible explanation might be related to the report that NO plays a major role in mediation of the antiproliferative effects of proinflammatory cytokines on cultured $\beta$ cells (QuintanaLopez et al. 2013), and that we found only a trivial and not significant effect of insulin on iNos expression and NO activity. The lack of a detectable positive interaction might also be due to the very strong effect of the cytokine mixture that could mask any additional effect of insulin. Moreover, certain cytokines induce production of ROS (Prause et al. 2016), and this effect may not be further increased by insulin. Additional studies are necessary in order to explore any further possible effects of insulin on cytokine-induced cell death.

We could also show that insulin effects are relatively selective for pancreatic $\beta$ cells, because cells from different origins, such as $\mathrm{CHO}$, HEK293 and NIH fibroblast cells (as well as AML12 liver and pheochromocytoma cells (Sampson et al. 2010), did not demonstrate insulininduced LDH release or decreased cellular reducing power. Interestingly, we found that HepG2 liver cells responded to prolonged insulin exposure with a slight increase in caspase $3 / 7$ activity, an indication that apoptosis mechanisms might be slightly activated. Yet, neither cytokine mix nor insulin had a significant effect on cellular reducing power despite their effects on caspase activity, suggesting that the minor increase in caspase activity in HepG2 cells is not sufficient to affect their viability.

While hyperinsulinemia is associated with pancreatic $\beta$ cell demise (Wang \& Jin 2009), insulin itself has not been considered to be a contributor to $\beta$ cell deterioration. Most studies attribute any deleterious effects of this association to overproduction of insulin by the $\beta$ cells that eventually results in a classical induction of ER stress, UPR and eventual death of the $\beta$ cell (Fonseca et al. 2011). Although the concentrations used in this study are unlikely to be attained in the blood during hyperinsulinemia, they are in accord with those used in other studies regarding insulin effects on its target tissues (Biswas et al. 2007, Guillen et al. 2008, Du \& Ding 2009). Furthermore, some studies report levels as high as $700-800 \mathrm{pM}$ (Movassat et al. 1997, Remington et al. 2015, Yang et al. 2015). Moreover, it should be noted that the concentration of insulin in the vicinity of the islets may be considerably higher than that in the serum. Interestingly, it was shown that exogenous insulin completely prevented apoptosis induced by serum withdrawal when given at picomolar or low nanomolar concentrations, but not at higher concentrations (Johnson et al. 2006). We would suggest, therefore, that the current study highlights another potential aspect of high nanomolar concentrations of insulin, namely that the secreted insulin per se, when present in the vicinity of the $\beta$ cells at high enough concentrations and for prolonged periods of time, might act as a proapoptotic adjuvant agent that promotes $\beta$ cell death. This notion is consistent with previous findings that have shown that insulin can increase ROS levels in target cells (Goldstein et al. 2005b), probably via the NOX family of NADPH oxidases (Guichard et al. 2008), several members of which

Published by Bioscientifica Ltd 
are expressed in pancreatic islets (Guichard et al. 2008). Insulin was also reported to induce apoptosis in glucosedeprived $\beta$ cells (Guillen et al. 2008) and potentiate the deleterious effects of $\mathrm{H}_{2} \mathrm{O}_{2}$ on $\beta$ cell survival (Sampson et al. 2010). Of special interest in this regard is our finding that insulin increased the expression of iNos and Trb3, factors whose expression is known to be increased by cytokines in pancreatic $\beta$ cells (Kanki et al. 2009, Humphrey et al. 2010, Kanwar 2010, Quintana-Lopez et al. 2013). Trb3 was recently shown to mediate FFA-induced apoptosis in pancreatic $\beta$ cells (Qin et al. 2014).

Insulin is generally considered to be a factor that positively affects cell proliferation and promotes $\beta$ cell survival (Wang \& Jin 2009). As shown in numerous studies by us and others (Gurevitch et al. 2010, Tseng et al. 2002), insulin mainly plays antiapoptotic roles and exerts its trophic effects on $\beta$-cells through an IRS2-mediated signaling pathway. Still, growth factors, such as insulin, might also induce ROS production and proapoptotic signals under certain circumstances (Porras et al. 2003, Bryson \& White 2012, Graham et al. 2012). Production of ROS for short periods is associated with an increase in glucose-stimulated insulin secretion, but excessive or sustained production of ROS is negatively correlated with the insulin secretory process and leads to $\beta$ cell death (Newsholme et al. 2007). This might be due to the relatively low levels of free radical detoxifying and redox-regulating enzymes, such as superoxide dismutase, glutathione peroxidase, catalase and thioredoxin in $\beta$ cells. The consequence of limited scavenging systems is that upon stimulation of the NADPH oxidase systems, ROS concentrations in $\beta$-cells may increase rapidly and thereby easily reach damaging levels (Newsholme et al. 2007). Support to this notion is provided by the fact that inhibition of Akt, which can mediate ROS production, abrogates the effects of insulin. Another possible mechanism for apoptosis-inducing effects could be related to effects of prolonged insulin signal stimulation on cell viability. Thus, it was reported that decreased IRS- 2 protein expression in $\beta$-cells, mediated via chronic activation of mTOR induced by chronic exposure to glucose, correlated with decreased PKB phosphorylation activation; this, in turn, was associated with increased caspase-9 activation, a marker of $\beta$-cell apoptosis (Briaud et al. 2005, Shigeyama et al. 2008). In support of this possibility is the report that $\beta$ cell apoptosis and markers of oxidative stress in response to a high-fat diet were decreased in mice expressing a mutated IR compared with wild-type mice (Tachibana et al. 2015).
Clearly, the mechanisms involved in pancreatic $\beta$ cell deterioration and death are many and varied and likely involve the myriad of steps and factors controlling $\beta$ cell proliferation (see review by Kulkarni (Kulkarni et al. 2012)). The results in this work support the concept (Aston-Mourney et al. 2008) that increased and sustained insulin levels that promote NADPH oxidase activity and ROS production may be detrimental to pancreatic $\beta$ cell survival. Hence, induction of increased insulin secretion in patients with obesity and insulin resistance that are already hyperinsulinemic may actually accelerate the deterioration of pancreatic $\beta$ cells, a consideration supported by the results presented in this report.

\section{Declaration of interest}

The authors declare that there is no conflict of interest that could be perceived as prejudicing the impartiality of the research reported.

\section{Funding}

This work was supported in part by grants from DCure-Diabetes Cure Israel (S R S) and the Israel Science Foundation (Y Z).

\section{References}

Allagnat F, Cunha D, Moore F, Vanderwinden JM, Eizirik DL \& Cardozo AK 2011 Mcl-1 downregulation by pro-inflammatory cytokines and palmitate is an early event contributing to beta-cell apoptosis. Cell Death and Differentiation 18 328-337. (doi:10.1038/ cdd.2010.105)

Allagnat F, Fukaya M, Nogueira TC, Delaroche D, Welsh N, Marselli L, Marchetti P, Haefliger JA, Eizirik DL \& Cardozo AK 2012 C/EBP homologous protein contributes to cytokine-induced proinflammatory responses and apoptosis in beta-cells. Cell Death and Differentiation 19 1836-1846. (doi:10.1038/cdd.2012.67)

An L, Wang Y, Wang C, Fan M, Han X, Xu G, Yuan G, Li H, Sheng Y, Wang M, et al. 2015 Protective effect of Schisandrae chinensis oil on pancreatic beta-cells in diabetic rats. Endocrine $\mathbf{4 8} 818-825$. (doi:10.1007/s12020-014-0375-y)

Aston-Mourney K, Proietto J, Morahan G \& Andrikopoulos S 2008 Too much of a good thing: why it is bad to stimulate the beta cell to secrete insulin. Diabetologia 51 540-545. (doi:10.1007/s00125-0080930-2)

Barazzoni R, Zanetti M, Gortan Cappellari G, Semolic A, Boschelle M, Codarin E, Pirulli A, Cattin L \& Guarnieri G 2012 Fatty acids acutely enhance insulin-induced oxidative stress and cause insulin resistance by increasing mitochondrial reactive oxygen species (ROS) generation and nuclear factor-kappaB inhibitor (IkappaB)-nuclear factor-kappaB (NFkappaB) activation in rat muscle, in the absence of mitochondrial dysfunction. Diabetologia 55 773-782. (doi:10.1007/s00125-0112396-x)

Beck A, Isaac R, Lavelin I, Hart Y, Volberg T, Shatz-Azoulay H, Geiger B \& Zick Y 2011 An siRNA screen identifies transmembrane 7 superfamily member 3 (TM7SF3), a seven transmembrane orphan receptor, as an inhibitor of cytokine-induced death of pancreatic beta cells. Diabetologia 54 2845-2855. (doi:10.1007/s00125-011-2277-3)

Published by Bioscientifica Ltd. 
Beck A, Vinik Y, Shatz-Azoulay H, Isaac R, Streim S, Jona G, Boura-Halfon S \& Zick Y 2013 Otubain 2 is a novel promoter of beta cell survival as revealed by siRNA high-throughput screens of human pancreatic islets. Diabetologia 56 1317-1326. (doi:10.1007/s00125-013-2889-x)

Bedoya FJ, Salguero-Aranda C, Cahuana GM, Tapia-Limonchi R, Soria B \& Tejedo JR 2012 Regulation of pancreatic beta-cell survival by nitric oxide: clinical relevance. Islets 4 108-118. (doi:10.4161/isl.19822)

Bhakkiyalakshmi E, Shalini D, Sekar TV, Rajaguru P, Paulmurugan R \& Ramkumar KM 2014 Therapeutic potential of pterostilbene against pancreatic beta-cell apoptosis mediated through Nrf2. British Journal of Pharmacology 171 1747-1757. (doi:10.1111/bph.12577)

Biswas S, Gupta MK, Chattopadhyay D \& Mukhopadhyay CK 2007 Insulin-induced activation of hypoxia-inducible factor-1 requires generation of reactive oxygen species by NADPH oxidase. American Journal of Physiology: Heart and Circulatory Physiology 292 H758-H766. (doi:10.1152/ajpheart.00718.2006)

Briaud I, Dickson LM, Lingohr MK, McCuaig JF, Lawrence JC \& Rhodes CJ 2005 Insulin receptor substrate- 2 proteasomal degradation mediated by a mammalian target of rapamycin (mTOR)-induced negative feedback down-regulates protein kinase B-mediated signaling pathway in beta-cells. Journal of Biological Chemistry $2802282-2293$. (doi:10.1074/jbc.m412179200)

Broniowska KA, Oleson BJ \& Corbett JA 2014 beta-Cell responses to nitric oxide. Vitamins and Hormones 95 299-322. (doi:10.1016/B978-0-12800174-5.00012-0)

Bryson BD \& White FM 2012 Signaling for death: tyrosine phosphorylation in the response to glucose deprivation. Molecular Systems Biology 8 591. (doi:10.1038/msb.2012.27)

Chan JY, Luzuriaga J, Maxwell EL, West PK, Bensellam M \& Laybutt DR 2015 The balance between adaptive and apoptotic unfolded protein responses regulates beta-cell death under ER stress conditions through XBP1, CHOP and JNK. Molecular and Cellular Endocrinology 413 189-201. (doi:10.1016/j.mce.2015.06.025)

Chetboun M, Abitbol G, Rozenberg K, Rozenfeld H, Deutsch A, Sampson SR \& Rosenzweig T 2012 Maintenance of redox state and pancreatic beta-cell function: role of leptin and adiponectin. Journal of Cellular Biochemistry 113 1966-1976. (doi:10.1002/jcb.24065)

Del Parigi A 2008 Insulin may have a role to play in protecting beta cells from deterioration in diabetes. Diabetologia 51 1340. (doi:10.1007/ s00125-008-1010-3)

Dembele K, Nguyen KH, Hernandez TA \& Nyomba BL 2009 Effects of ethanol on pancreatic beta-cell death: interaction with glucose and fatty acids. Cell Biology and Toxicology 25 141-152. (doi:10.1007/ s10565-008-9067-9)

Du K \& Ding J 2009 Insulin regulates TRB3 and other stress-responsive gene expression through induction of C/EBPbeta. Molecular Endocrinology 23 475-485. (doi:10.1210/me.2008-0284)

Eizirik DL, Cardozo AK \& Cnop M 2008 The role for endoplasmic reticulum stress in diabetes mellitus. Endocrine Reviews 29 42-61. (doi:10.1210/er.2007-0015)

Fawcett J, Hamel FG, Bennett RG, Vajo Z \& Duckworth WC 2001 Insulin and analogue effects on protein degradation in different cell types. Dissociation between binding and activity. Journal of Biological Chemistry 276 11552-11558. (doi:10.1074/jbc.M007988200)

Fernandez AM, Kim JK, Yakar S, Dupont J, Hernandez-Sanchez C, Castle AL, Filmore J, Shulman GI \& Le Roith D 2001 Functional inactivation of the IGF-I and insulin receptors in skeletal muscle causes type 2 diabetes. Genes and Development 15 1926-1934. (doi:10.1101/gad.908001)

Fonseca SG, Gromada J \& Urano F 2011 Endoplasmic reticulum stress and pancreatic beta-cell death. Trends in Endocrinology and Metabolism 22 266-274. (doi:10.1016/j.tem.2011.02.008)

Fu J, Zheng H, Wang H, Yang B, Zhao R, Lu C, Liu Z, Hou Y, Xu Y, Zhang Q, et al. 2015 Protective role of nuclear factor E2-related factor 2 against acute oxidative stress-induced pancreatic beta-cell damage. Oxidative Medicine and Cellular Longevity 2015 1-12. (doi:10.1155/2015/639191)

Furukawa S, Fujita T, Shimabukuro M, Iwaki M, Yamada Y, Nakajima Y, Nakayama O, Makishima M, Matsuda M \& Shimomura I 2004 Increased oxidative stress in obesity and its impact on metabolic syndrome. Journal of Clinical Investigation 114 1752-1761. (doi:10.1172/JCI21625)

Goldstein BJ, Mahadev K \& Wu X 2005a Redox paradox: insulin action is facilitated by insulin-stimulated reactive oxygen species with multiple potential signaling targets. Diabetes 54 311-321. (doi:10.2337/ diabetes.54.2.311)

Goldstein BJ, Mahadev K, Wu X, Zhu L \& Motoshima H 2005 b Role of insulin-induced reactive oxygen species in the insulin signaling pathway. Antioxidants and Redox Signaling 7 1021-1031. (doi:10.1089/ ars.2005.7.1021)

Graham NA, Tahmasian M, Kohli B, Komisopoulou E, Zhu M, Vivanco I, Teitell MA, Wu H, Ribas A, Lo RS, et al. 2012 Glucose deprivation activates a metabolic and signaling amplification loop leading to cell death. Molecular Systems Biology 8 589. (doi:10.1038/msb.2012.20)

Guichard C, Moreau R, Pessayre D, Epperson TK \& Krause KH 2008 NOX family NADPH oxidases in liver and in pancreatic islets: a role in the metabolic syndrome and diabetes? Biochemical Society Transactions 36 920-929. (doi:10.1042/BST0360920)

Guillen C, Bartolome A, Nevado C \& Benito M 2008 Biphasic effect of insulin on beta cell apoptosis depending on glucose deprivation. FEBS Letters 582 3855-3860. (doi:10.1016/j.febslet.2008.10.020)

Gurevitch D, Boura-Halfon S, Isaac R, Shahaf G, Alberstein M, Ronen D, Lewis EC \& Zick Y 2010 Elimination of negative feedback control mechanisms along the insulin signaling pathway improves beta-cell function under stress. Diabetes 59 2188-2197. (doi:10.2337/db090890)

Gwinn DM, Shackelford DB, Egan DF, Mihaylova MM, Mery A Vasquez DS, Turk BE \& Shaw RJ 2008 AMPK phosphorylation of raptor mediates a metabolic checkpoint. Molecular Cell 30 214-226. (doi:10.1016/j.molcel.2008.03.003)

Hah J, Jo I, Chakrabarti R \& Jung CY 1992 Demonstration of an insulininsensitive storage pool of glucose transporters in rat hepatocytes and HepG2 cells. Journal of Cellular Physiology 152 56-63. (doi:10.1002/ jcp.1041520108)

He Y, Sun S, Sha H, Liu Z, Yang L, Xue Z, Chen H \& Qi L 2010 Emerging roles for XBP1, a sUPeR transcription factor. Gene Expression 15 13-25. (doi:10.3727/105221610X12819686555051)

Herold KC, Vignali DA, Cooke A \& Bluestone JA 2013 Type 1 diabetes: translating mechanistic observations into effective clinical outcomes. Nature Reviews Immunology 13 243-256. (doi:10.1038/nri3422)

Hou N, Torii S, Saito N, Hosaka M \& Takeuchi T 2008 Reactive oxygen species-mediated pancreatic beta-cell death is regulated by interactions between stress-activated protein kinases, p38 and c-Jun N-terminal kinase, and mitogen-activated protein kinase phosphatases. Endocrinology 149 1654-1665. (doi:10.1210/en.20070988)

Humphrey RK, Newcomb CJ, Yu SM, Hao E, Yu D, Krajewski S, Du K \& Jhala US 2010 Mixed lineage kinase-3 stabilizes and functionally cooperates with TRIBBLES-3 to compromise mitochondrial integrity in cytokine-induced death of pancreatic beta cells. Journal of Biological Chemistry 285 22426-22436. (doi:10.1074/jbc. M110.123786)

Jensen M \& De Meyts P 2009 Molecular mechanisms of differential intracellular signaling from the insulin receptor. Vitamins and Hormones 80 51-75. (doi:10.1016/S0083-6729(08)00603-1)

Johnson JD, Bernal-Mizrachi E, Alejandro EU, Han Z, Kalynyak TB, Li H, Beith JL, Gross J, Warnock GL, Townsend RR, et al. 2006 Insulin protects islets from apoptosis via Pdx1 and specific changes in the human islet proteome. PNAS 103 19575-19580. (doi:10.1073/ pnas.0604208103) http://joe.endocrinology-journals.org

DOI: 10.1530/JOE-15-0505
() 2016 Society for Endocrinology Printed in Great Britain 
Kajimoto Y \& Kaneto H 2004 Role of oxidative stress in pancreatic betacell dysfunction. Annals of the New York Academy of Sciences 1011 168-176. (doi:10.1196/annals.1293.017)

Kanki K, Kawamura T \& Watanabe Y 2009 Control of ER stress by a chemical chaperone counteracts apoptotic signals in IFN-gammatreated murine hepatocytes. Apoptosis 14 309-319. (doi:10.1007/ s10495-009-0318-x)

Kanwar YS 2010 TRB3: an oxidant stress-induced pseudokinase with a potential to negatively modulate MCP-1 cytokine in diabetic nephropathy. American Journal of Physiology: Renal Physiology 299 F963-F964. (doi:10.1152/ajprenal.00479.2010)

Kitiphongspattana K, Khan TA, Ishii-Schrade K, Roe MW, Philipson LH \& Gaskins HR 2007 Protective role for nitric oxide during the endoplasmic reticulum stress response in pancreatic beta-cells. American Journal of Physiology: Endocrinology and Metabolism 292 E1543-E1554. (doi:10.1152/ajpendo.00620.2006)

Konishi H, Tanaka M, Takemura Y, Matsuzaki H, Ono Y, Kikkawa U \& Nishizuka Y 1997 Activation of protein kinase C by tyrosine phosphorylation in response to H2O2. PNAS 94 11233-11237. (doi:10.1073/pnas.94.21.11233)

Kulkarni RN, Mizrachi EB, Ocana AG \& Stewart AF 2012 Human beta-cell proliferation and intracellular signaling: driving in the dark without a road map. Diabetes 61 2205-2213. (doi:10.2337/db12-0018)

Laybutt DR, Kaneto H, Hasenkamp W, Grey S, Jonas JC, Sgroi DC, Groff A, Ferran C, Bonner-Weir S, Sharma A, et al. 2002 Increased expression of antioxidant and antiapoptotic genes in islets that may contribute to beta-cell survival during chronic hyperglycemia. Diabetes 51 413-423. (doi:10.2337/diabetes.51.2.413)

Lin N, Chen H, Zhang H, Wan X \& Su Q 2012 Mitochondrial reactive oxygen species (ROS) inhibition ameliorates palmitate-induced INS-1 beta cell death. Endocrine 42 107-117. (doi:10.1007/s12020-0129633-z)

Liu J, Wang X, Peng Z, Zhang T, Wu H, Yu W, Kong D, Liu Y, Bai H, Liu R, et al. 2015 The effects of insulin pre-administration in mice exposed to ethanol: alleviating hepatic oxidative injury through anti-oxidative anti-apoptotic activities and deteriorating hepatic steatosis through SRBEP-1c activation. International Journal of Biological Sciences $\mathbf{1 1}$ 569-586. (doi:10.7150/ijbs.11039)

Lortz S, Lenzen S \& Mehmeti I 2015 Impact of scavenging hydrogen peroxide in the endoplasmic reticulum for beta cell function. Journal of Molecular Endocrinology 55 21-29. (doi:10.1530/JME-15-0132)

Lu H, Koshkin V, Allister EM, Gyulkhandanyan AV \& Wheeler MB 2010 Molecular and metabolic evidence for mitochondrial defects associated with beta-cell dysfunction in a mouse model of type 2 diabetes. Diabetes 59 448-459. (doi:10.2337/db09-0129)

Mahadev K, Wu X, Zilbering A, Zhu L, Lawrence JT \& Goldstein BJ 2001 Hydrogen peroxide generated during cellular insulin stimulation is integral to activation of the distal insulin signaling cascade in 3T3-L1 adipocytes. Journal of Biological Chemistry $27648662-48669$. (doi:10.1074/jbc.M105061200)

May JM \& de Haen C 1979 Insulin-stimulated intracellular hydrogen peroxide production in rat epididymal fat cells. Journal of Biological Chemistry 254 2214-2220.

Mehmeti I, Lortz S, Elsner M \& Lenzen S 2014 Peroxiredoxin 4 improves insulin biosynthesis and glucose-induced insulin secretion in insulin-secreting INS-1E cells. Journal of Biological Chemistry 289 26904-26913. (doi:10.1074/jbc.M114.568329)

Movassat J, Saulnier C, Serradas P \& Portha B 1997 Impaired development of pancreatic beta-cell mass is a primary event during the progression to diabetes in the GK rat. Diabetologia 40 916-925. (doi:10.1007/s001250050768)

Mukherjee SP, Lane RH \& Lynn WS 1978 Endogenous hydrogen peroxide and peroxidative metabolism in adipocytes in response to insulin and sulfhydryl reagents. Biochemical Pharmacology 27 2589-2594. (doi:10.1016/0006-2952(78)90332-5)
Muller D, Jones PM \& Persaud SJ 2006 Autocrine anti-apoptotic and proliferative effects of insulin in pancreatic beta-cells. FEBS Letters 580 6977-6980. (doi:10.1016/j.febslet.2006.11.066)

Nakamura U, Iwase M, Uchizono Y, Sonoki K, Sasaki N, Imoto H, Goto D \& Iida M 2006 Rapid intracellular acidification and cell death by $\mathrm{H} 2 \mathrm{O} 2$ and alloxan in pancreatic beta cells. Free Radical Biology and Medicine 40 2047-2055. (doi:10.1016/j.freeradbiomed.2006.01.038)

Navarro-Tableros V, Sanchez-Soto MC, Garcia S \& Hiriart M 2004 Autocrine regulation of single pancreatic beta-cell survival. Diabetes 53 2018-2023. (doi:10.2337/diabetes.53.8.2018)

Newsholme P, Haber EP, Hirabara SM, Rebelato EL, Procopio J, Morgan D, Oliveira-Emilio HC, Carpinelli AR \& Curi R 2007 Diabetes associated cell stress and dysfunction: role of mitochondrial and nonmitochondrial ROS production and activity. Journal of Physiology $\mathbf{5 8 3}$ 9-24. (doi:10.1113/jphysiol.2007.135871)

Palsamy P \& Subramanian S 2010 Ameliorative potential of resveratrol on proinflammatory cytokines, hyperglycemia mediated oxidative stress, and pancreatic beta-cell dysfunction in streptozotocin-nicotinamideinduced diabetic rats. Journal of Cellular Physiology 224 423-432. (doi:10.1002/jcp.22138)

Patel NA, Apostolatos HS, Mebert K, Chalfant CE, Watson JE, Pillay TS, Sparks J \& Cooper DR 2004 Insulin regulates protein kinase CbetaII alternative splicing in multiple target tissues: development of a hormonally responsive heterologous minigene. Molecular Endocrinology 18 899-911. (doi:10.1210/me.2003-0391)

Porras A, Zuluaga S, Valladares A, Alvarez AM, Herrera B, Fabregat I \& Benito M 2003 Long-term treatment with insulin induces apoptosis in brown adipocytes: role of oxidative stress. Endocrinology $\mathbf{1 4 4}$ 5390-5401. (doi:10.1210/en.2003-0622)

Prause M, Berchtold LA, Urizar AI, Hyldgaard Trauelsen M, Billestrup N, Mandrup-Poulsen T \& Storling J 2016 TRAF2 mediates JNK and STAT3 activation in response to IL-1beta and IFNgamma and facilitates apoptotic death of insulin-producing beta-cells. Molecular and Cellular Endocrinology 420 24-36. (doi:10.1016/j.mce.2015.11.021)

Qin J, Fang N, Lou J, Zhang W, Xu S, Liu H, Fang Q, Wang Z, Liu J, Men X, et al. 2014 TRB3 is involved in free fatty acid-induced INS-1derived cell apoptosis via the protein kinase C delta pathway. PLoS ONE 9 e96089. (doi:10.1371/journal.pone.0096089)

Quintana-Lopez L, Blandino-Rosano M, Perez-Arana G, CebadaAleu A, Lechuga-Sancho A, Aguilar-Diosdado M \& Segundo C 2013 Nitric oxide is a mediator of antiproliferative effects induced by proinflammatory cytokines on pancreatic beta cells. Mediators of Inflammation 2013 1-10. (doi:10.1155/2013/905175)

Remington GJ, Teo C, Wilson V, Chintoh A, Guenette M, Ahsan Z, Giacca A \& Hahn MK 2015 Metformin attenuates olanzapine-induced hepatic, but not peripheral insulin resistance. Journal of Endocrinology 227 71-81. (doi:10.1530/JOE-15-0074)

Robertson RP 2004 Chronic oxidative stress as a central mechanism for glucose toxicity in pancreatic islet beta cells in diabetes. Journal of Biological Chemistry 279 42351-42354. (doi:10.1074/jbc.R400019200)

Ron D \& Walter P 2007 Signal integration in the endoplasmic reticulum unfolded protein response. Nature Reviews Molecular Cell Biology $\mathbf{8}$ 519-529. (doi:10.1038/nrm2199)

Sampson SR, Bucris E, Horovitz-Fried M, Parnas A, Kahana S, Abitbol G, Chetboun M, Rosenzweig T, Brodie C \& Frankel S 2010 Insulin increases $\mathrm{H}(2) \mathrm{O}$ (2)-induced pancreatic beta cell death. Apoptosis 15 1165-1176. (doi:10.1007/s10495-010-0517-5)

Shigeyama Y, Kobayashi T, Kido Y, Hashimoto N, Asahara S, Matsuda T, Takeda A, Inoue T, Shibutani Y, Koyanagi M, et al. 2008 Biphasic response of pancreatic beta-cell mass to ablation of tuberous sclerosis complex 2 in mice. Molecular and Cellular Biology 28 2971-2979. (doi:10.1128/MCB.01695-07)

Tachibana K, Sakurai K, Yokoh H, Ishibashi T, Ishikawa K, Shirasawa T \& Yokote K 2015 Mutation in insulin receptor attenuates oxidative stress and apoptosis in pancreatic beta-cells induced by nutrition http://joe.endocrinology-journals.org

DOI: $10.1530 / \mathrm{JOE}-15-0505$
() 2016 Society for Endocrinology Printed in Great Britain 
excess: reduced insulin signaling and ROS. Hormone and Metabolic Research 47 176-183. (doi:10.1055/s-0034-1389990)

Tersey SA, Maier B, Nishiki Y, Maganti AV, Nadler JL \& Mirmira RG 2014 12-lipoxygenase promotes obesity-induced oxidative stress in pancreatic islets. Molecular and Cellular Biology 34 3735-3745. (doi:10.1128/MCB.00157-14)

Tiedge M, Lortz S, Drinkgern J \& Lenzen S 1997 Relation between antioxidant enzyme gene expression and antioxidative defense status of insulin-producing cells. Diabetes 46 1733-1742. (doi:10.2337/ diab.46.11.1733)

Tseng YH, Ueki K, Kriauciunas KM \& Kahn CR 2002 Differential roles of insulin receptor substrates in the anti-apoptotic function of insulinlike growth factor-1 and insulin. Journal of Biological Chemistry 277 31601-31611. (doi:10.1074/jbc.M202932200)

Vanderford NL 2010 Defining the regulation of IL-1beta- and CHOPmediated beta-cell apoptosis. Islets 2 334-336. (doi:10.4161/isl.2.5.13095)

Vasu S, McClenaghan NH, McCluskey JT \& Flatt PR 2014 Mechanisms of toxicity by proinflammatory cytokines in a novel human pancreatic beta cell line 1.1B4. Biochimica et Biophysica Acta 1840 136-145. (doi:10.1016/j.bbagen.2013.08.022)

Wali JA, Gurzov EN, Fynch S, Elkerbout L, Kay TW, Masters SL \& Thomas HE 2014 Activation of the NLRP3 inflammasome complex is not required for stress-induced death of pancreatic islets. PLOS ONE 9 e113128. (doi:10.1371/journal.pone.0113128)

Walter P \& Ron D 2011 The unfolded protein response: from stress pathway to homeostatic regulation. Science 334 1081-1086. (doi:10.1126/science.1209038)

Wang Q \& Jin T 2009 The role of insulin signaling in the development of beta-cell dysfunction and diabetes. Islets 1 95-101. (doi:10.4161/ isl.1.2.9263)

Yang ZH, Inoue S, Taniguchi Y, Miyahara H, Iwasaki Y, Takeo J, Sakaue H \& Nakaya Y 2015 Long-term dietary supplementation with saury oil attenuates metabolic abnormalities in mice fed a high-fat diet: combined beneficial effect of omega-3 fatty acids and long-chain monounsaturated fatty acids. Lipids in Health and Disease 14155. (doi:10.1186/s12944-015-0161-8)

Received in final form 22 June 2016

Accepted 27 June 2016
(C) 2016 Society for Endocrinology Printed in Great Britain
Published by Bioscientifica Ltd 